Article

\title{
Seismic Risk Assessment of a Novel Self-Centering Precast Concrete Frame under Near-Fault Ground Motions
}

\author{
Fangfang Geng ${ }^{1,2}$, Youliang Ding ${ }^{3, *}$, Honglei $\mathrm{Wu}^{2}$ and Kang Yang ${ }^{3}$ \\ 1 Nanjing Institute of Technology, Nanjing 211176, China; j00000002962@njit.edu.cn \\ 2 Tongji Architectural Design (Group) Co., Ltd., Shanghai 200092, China; 8whl@tjad.cn \\ 3 Key Laboratory of Concrete and Prestressed Concrete Structures of Ministry of Education, \\ Southeast University, Nanjing 210096, China; youngseu@163.com \\ * Correspondence: civilding@seu.edu.cn
}

Received: 29 July 2020; Accepted: 12 September 2020; Published: 18 September 2020

Featured Application: The novel self-centering precast concrete (SCPC) frame with hysteretic dampers has favorable seismic behavior and achieves the desirable demands at the design basis earthquake (DBE) and the maximum considered earthquake (MCE) seismic levels under the near-fault earthquake waves. In addition, the novel connection shows desirable energy consumption and self-recovering capacities, which is applicable to the precast structure in near-fault seismic region.

\begin{abstract}
The damage to structures caused by the velocity pulse effect of near-fault earthquake waves cannot be ignored, yet there are few studies on the risk assessment of seismic performance for precast concrete frame under near-fault earthquake waves. A novel self-centering precast concrete (SCPC) frame with hysteretic dampers is proposed to obtain great self-recovering and energy consumption characteristics. To accurately assess the seismic behaviors of the novel SCPC frame under the near-fault earthquake waves, a prototype structure is modelled and elastoplastic dynamic analysis is conducted at the design basis earthquake (DBE) and the maximum considered earthquake (MCE) seismic levels. Incremental dynamic analysis and the vulnerability analysis are performed. Annual and 50-year exceeding probabilities of the novel SCPC frame are calculated afterwards. In addition, the reinforced concrete (RC)frame and the traditional SCPC frame are also modelled, whose section sizes, reinforcements arrangement and seismic intensity are consistent with the novel SCPC frame. The dynamic time-history analysis at the two seismic levels are also carried out for two types of frames. The analysis results demonstrate that the novel SCPC frame has great seismic performance and low seismic risk possibility under the near-fault earthquakes loading.
\end{abstract}

Keywords: risk assessment; self-centering; hysteretic dampers; DBE and MCE levels; incremental dynamic analysis; vulnerability analysis

\section{Introduction}

At present, the velocity pulse effect caused by near-fault earthquake waves has attracted the extensive attention of researchers. Although the Imperial Valley earthquake in 1979, the Northridge earthquake in 1994, the Kobe earthquake in 1995, the Kocaeli earthquake and Chi-Chi earthquake in 1999 are all moderate earthquakes, they caused serious damage and loss of life and damage to structures [1]. From the existing strong earthquake records, the predominant velocity pulse emerges from either forward directivity or fling step effects [2-5]. Forward directivity effects show that the component perpendicular to the fault has a strong velocity pulse and fling step effects show residual 
and irrecoverable displacement due to the relative movements of ruptures [6-8]. Hence, the velocity pulse effect of near-fault earthquake waves can increase the seismic energy and cause serious damage to the structure and leave a permanent displacement. Different from the common far-field earthquake waves, short-duration and high-energy characteristics of the near-fault earthquake waves are a great potential destructive threat and thus increase the seismic requirement of structures [9].

The unique velocity pulse effect has been studied by many researchers on different structural systems [10]. Fibio et al. studied the influence of near-fault earthquake waves on the isolation structure with high damping rubber bearing [11]. At the same time, the comprehensive effects of horizontal and vertical ground motion components are considered and the numerical analysis of the bi-reinforcement concrete buildings is carried out according to the European seismic code. Mortezaei et al. introduced the influence on the seismic performance of the original reinforced concrete $(\mathrm{RC})$ structure and RC structure strengthened by Fiber Reinforced Polymer (FRP)at the near-fault earthquake waves loading [12]. The results showed that the strengthening technology of FPR can improve the rigidity, strength and lateral displacement capacity of the structure. Babak et al. analyzed the important influence of the velocity pulse effect of near-fault earthquake waves on the seismic performance of elastic frame and inelastic frame [13]. The results showed that the early yielding occurs at the higher storied of the structure when the natural vibration period is longer than the pulse period. With the increase of the seismic intensity, the ductility demands move to the bottom stories. The change rule is opposite when the natural vibration period is shorter than the pulse period. Chin-Hsiung Lou et al. studied the influence of near-fault earthquake waves from the Chi-Chi earthquake on the seismic performance of the structure [14]. Based on the test study, the response of a single degree of the freedom inelastic system is calculated by the improved nonlinear hysteretic model. According to the nonlinear elastic response spectrum, the variation of base shear coefficient is discussed. Reza Sehhati et al. analyzed the impulse effect of near-fault earthquake waves on the multi-story building and 54 near-fault earthquake wave tests were carried out for three kind of multi-story building [15]. Besides, when the ratio of pulse period and the basic period are in the range of $0.5 \sim 2.5$, the equivalent pulse model can better reflect the influence of forward directionality on the structure. From the aforementioned study, seismic risk assessments of the precast concrete structures under near-fault earthquake waves using the fragility analysis has been little reported in the literature [16].

Since the velocity pulse effect of near-fault earthquake waves can generate more significant inelastic deformation, many structural systems with high ductility and effective seismic energy dissipation have been developed in recent years. The self-centering reinforced concrete frame using the unbonded prestressed tendons have been proposed, which can maintain good self-restoring ability and retain minimal residual deformation [17-19]. Priestley and Tao proposed the concept of assembling precast components with unbonded tendons and the tests of connection and frame were also carried out afterwards [20]. The results showed the residual deformation of the joint was negligible and shear capacity of the joints were obviously improved. EI-Sheikh et al. established the analysis models of some 6-story and 4-span precast concrete frames using the elaborate finite elements in light of the different seismic regions and sites [21]. Pushover analysis and elastoplastic dynamic analysis based on 16 seismic waves were also carried out. The results displayed frames were in nonlinear elastic state, the damage was small and collapse could be avoided. Cheok et al. evaluated the seismic behaviors of a precast hybrid frame using the mix beam-column connections, the seismic energy consumption capacity of joints was improved through the yielding of ordinary reinforcements. A versatile hysteretic model simulating the nonlinear behavior of the joint area was proposed [22]. Morgen et al. used a new kind of friction damper installed on the beam-column joint with unboned tendons and proposed the seismic design method of the frame with the novel connections [23]. In addition, pushover analysis of the multi-story frame with the damper was carried out under the low cyclic loadings. The results showed that the frictions can provide supplemental energy dissipation, the residual deformation of the connection was minimal and the friction device was easy to replace. Geoffery et al. conducted the low cyclic load tests of two internal and external beam-column connections specimens with the 
energy dissipation devices (HF2V). The results showed the HF2V device can effectively enhance the energy dissipation and self-recovering characteristics when HF2V devices were reliably anchored [24]. In addition, Geoffery et al. established the mechanical model of precast beam-column connection using the HF2V devices under low cyclic repeated load [25]. Lu et al. designed the two story two way and three story three way scaled self-centering precast concrete frames and conducted a shake table test [26]. The experimental results showed that the seismic behavior and self-restoring capacity of the frame were excellent. They recommended that seismic energy dissipation devices can be added to enhance the seismic behavior of the precast frame.

To further enhance the energy consumption capacity, maintain the self-recovering capacity and reduce the local concrete damage; this study develops a new kind of hybrid self-centering precast (SCPC) frame joint with hysteretic dampers. In this novel connection, Post-tensioned (PT) tendons undertake moment and maintain the self-recovering capability after the ground motion loadings. The hysteretic dampers are arranged at the beam end to dissipate seismic energy and have no interference with the floor slab. To investigate the seismic risk assessment of the novel SCPC frame under near fault earthquake waves, a prototype frame with the novel SCPC connection is modelled and dynamic time-history analysis is performed at the design basis earthquake (DBE) and the maximum considered earthquake (MCE) seismic levels. Incremental dynamic analysis and vulnerability analysis are carried out afterwards and annual and 50-year exceeding probabilities of two limit states are obtained. In addition, the elastoplastic dynamic analysis of the RC frame and the traditional SCPC frame are also performed. Considering the near-fault's strong velocity pulse effect, the analysis results validate the great seismic performance and low seismic risk possibility of the novel SCPC frame.

\section{Basic Characteristics of Novel SCPC Connection}

\subsection{Construction of Connection}

The novel SCPC hybrid joint is a new ductile connection, the deformations of precast beams and columns are within the elastic range and the inelastic damage of beams and column is minimal. The inelastic damage is usually concentrated in an easily replaceable energy dissipation device. Figure 1a illustrates the detailed construction of the novel joint. One duct is arranged at the central axis of the precast beam section and unbonded tendons are arranged along the central axis of the beam horizontally. PT tendons not only assemble the precast beam and column in the construction stage but also resist the bending moment in the use stage under the seismic actions. If the moment is large beyond the critical opening moment, the gap-opening of the hybrid joint has occurred. The length and the stresses of PT tendons increase subsequently. The residual deformation is eliminated after the earthquake due to the characteristic of the self-recovering of prestressed tendons provided. Shear force at the beam end is undertaken by the friction at the beam-column interface caused by tendons and the friction bolts. The steel plate is shop fabricated in the column through the embedded part to reduce the local concrete damage. As shown in Figure 1a, the hysteretic dampers are installed at the upper and lower part of the beam end and welded between the steel connectors and the steel plates. The yield point of steel used in hysteretic dampers is low and the yield point is only $235 \mathrm{~N} / \mathrm{mm}^{2}$. In addition, the slot area of long strip on the steel plate will firstly produce in-plane plastic deformation. Hence, the hysteretic damper can enter the yielding state faster under the seismic loadings and then dissipate seismic energy by generating large plastic deformation after yielding. Compared with the out-of-plane buckling hysteretic damper, the in-plane buckling hysteretic damper has the advantage of large initial stiffness, high bearing capacity and good energy dissipation capability. The four steel connectors are bolted on the two sides of the beam and every steel connector uses two high strength friction bolts. The other side of the steel connector is welded with the hysteretic damper, in order to fix the damper and limit the damper's displacement. Therefore, the mechanical principle of the novel connection is-shear force at the beam end is taken by friction and the moment is undertaken by unbonded 
prestressed tendons and hysteretic dampers, PT tendons provide the self-recovering and hysteretic dampers improve energy consumption characteristics.

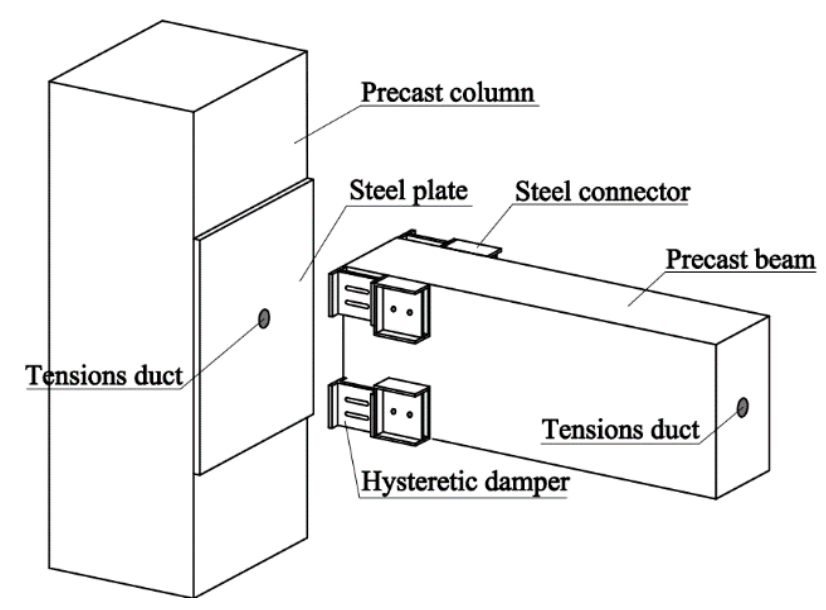

(a) Before assembly of the novel SCPC beam-column joint

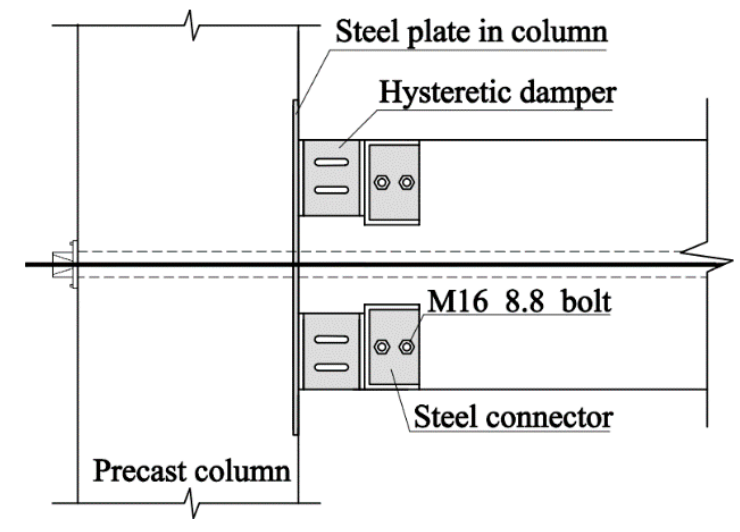

(b) After assembly of the novel SCPC connection

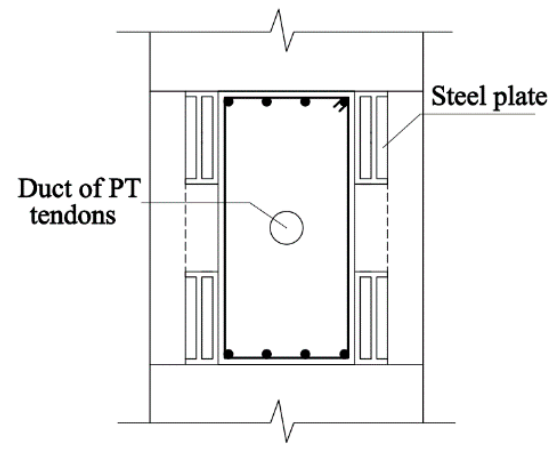

(c) beam section

Figure 1. Details of construction of the novel self-centering precast concrete (SCPC) connection.

\subsection{Mechanical Behavior Analysis of Hysteretic Dampers}

The hysteretic dampers improve the seismic energy dissipation capability of the novel beam-column connection due to their good plastic hysteresis performance, which generates large stresses and large deformations after yielding. Figure 2 shows the construction of the hysteretic damper. For the novel frame, the high initial stiffness of the hysteretic damper can increase structural stiffness to limit the structural displacement under the minor earthquake and generate significant plastic deformation after yielding to dissipate the seismic energy under the major earthquake. Therefore, 
the hysteretic damper must have relatively large initial stiffness and the good seismic energy capability. The section size of the hysteretic damper is determined according to the required stiffness and yield strength. The steel plate of the hysteretic dampers with a rectangular slot only occur in-plane deformation and can effectively avoid out of plane bulking. Three-dimensional solid element models are established using ABAQUS software to clearly determine the hysteretic behavior of the novel SCPC joint. The eight-node, hexahedral linear reduced integral solid elements C3D8R are adopted to accurately simulate a hysteretic damper. The 2-node linear 3D truss elements T3D2 are used to simulate the reinforcement and unbonded tendons. Figure 3 a displays the three-dimensional numerical simulation model of the new joint in ABAQUS and the hysteretic curve of new joint with a hysteretic damper under the cyclic loading, respectively. Energy consumption coefficient $\beta_{E}$ is an important performance index to measure the energy consumption capacity of novel SCPC connection [27]. $\beta_{E}$ is the ratio of the hysteresis loop area of the SCPC joint and that of the two line elastoplastic system with the same bending strength. From Figure $3 \mathrm{~b}$ we can see that the hysteretic curve $M-\theta_{r}$ is a typical double flag-shape, where $\theta_{r}$ is the connection rotation at the beam-column interface. The hysteretic loops become much plumper and the energy consumption coefficient $\beta_{E}$ is 0.42 , which indicates that the energy consumption capacity of the new connection with hysteretic dampers is sufficient.

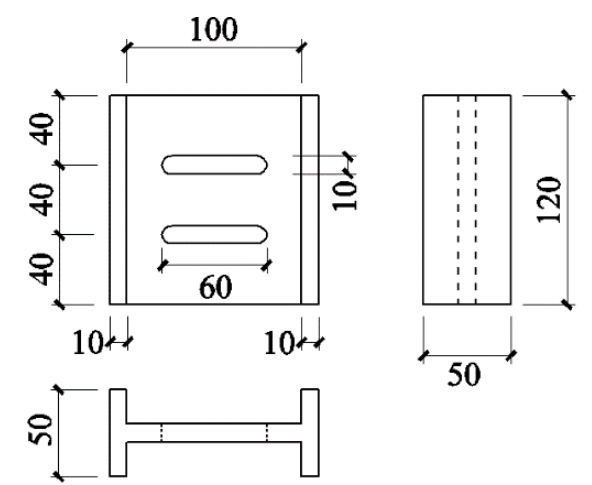

Figure 2. Details of the hysteretic dampers.

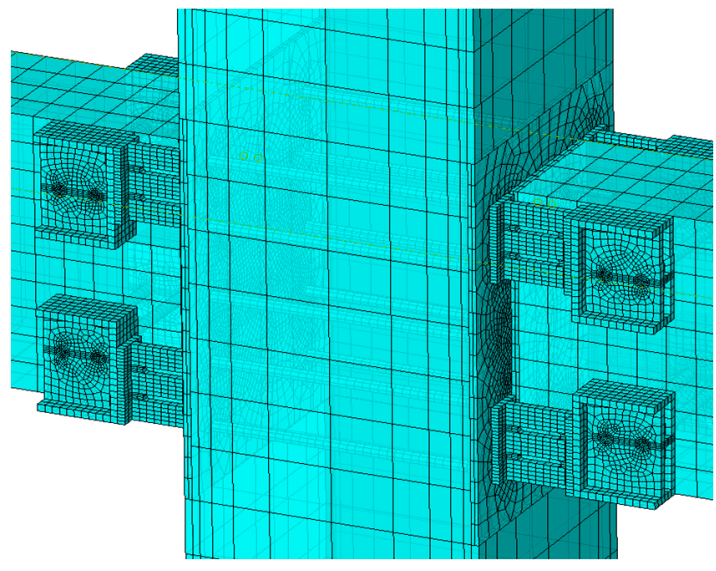

(a) Three-dimensional connection model of Abaqus

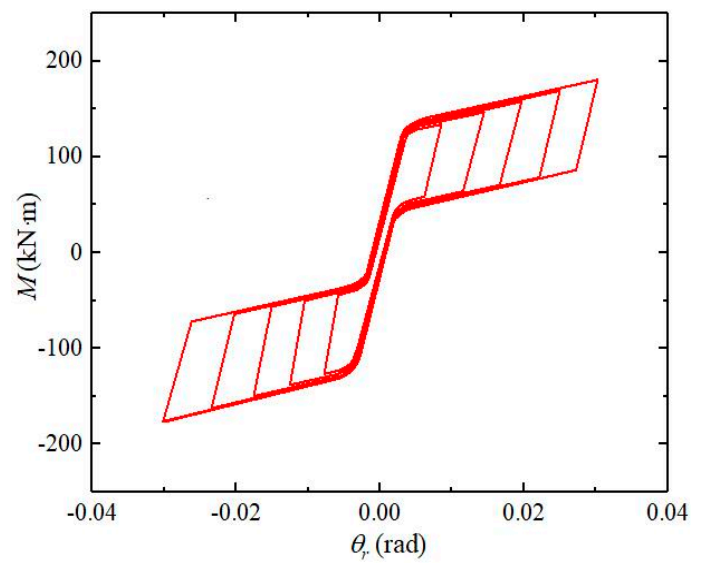

(b) Hysteretic curve of the novel connection

Figure 3. Three-dimensional model of hysteretic dampers and hysteretic curve of the novel joint.

To validate the numerical model and study the seismic behavior of the novel joint, the cyclic loading test of a full-sized novel SCPC connection specimen with hysteretic dampers was conducted. The details of the cyclic loading tests setup is shown in Figure 4. The hinge support was installed on the strong floor and the precast column was hinged. The displacement of the column top was constrained by the support beam and reaction wall. A 50t MTS actuator was fixed on the strong floor 
to apply the cyclic loading on the beam end. The horizontal displacement transducers were installed on the upper and lower surfaces of the beam end to measure the deformation of the beam end. $M$ was the moment at the beam end. The connection rotation $\theta_{r}$ was calculated by the absolute length of opening and compression between the upper and lower of beam end and the distance of the horizontal transducers. Figure 5 shows the comparison of hysteresis curve between the numerical simulation and test results. The numerical simulation results agree with the experimental data on the whole, such as gap opening and closing, energy consumption and self-centering characteristics.

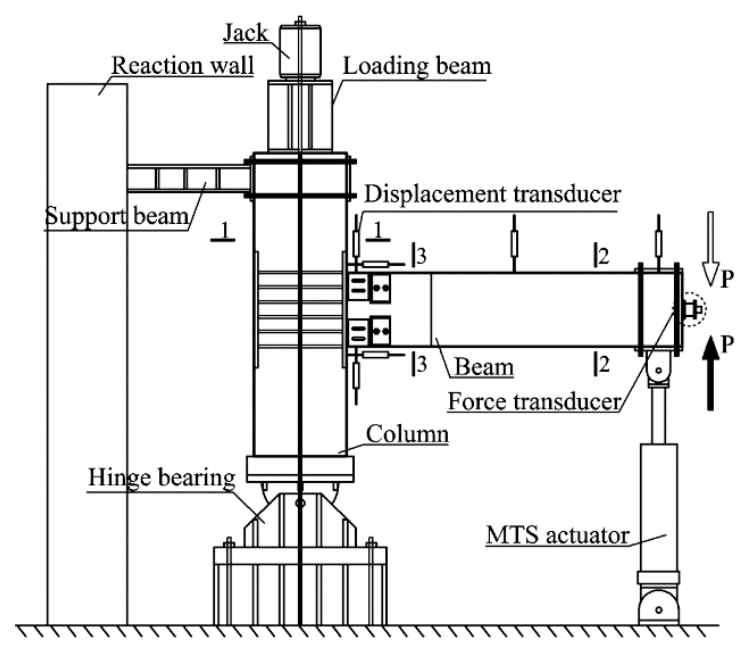

(a) Illustration of test setup

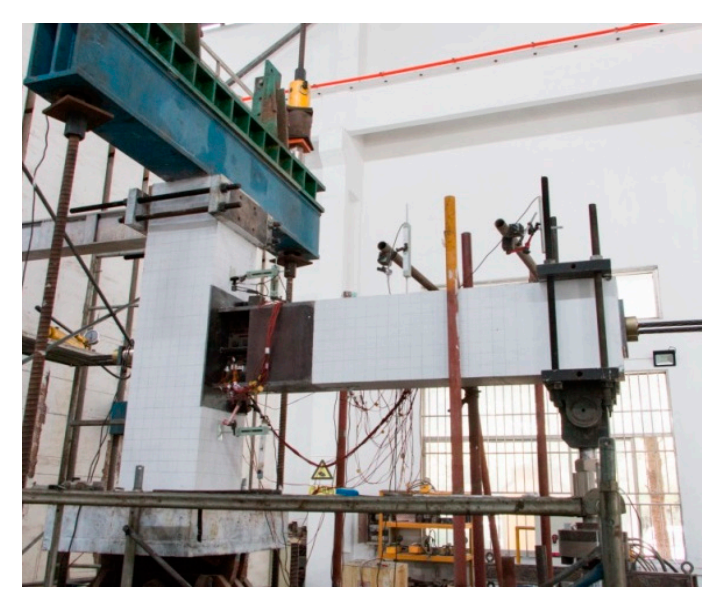

(b) Photograph of the test setup

Figure 4. Cyclic loading test set up.

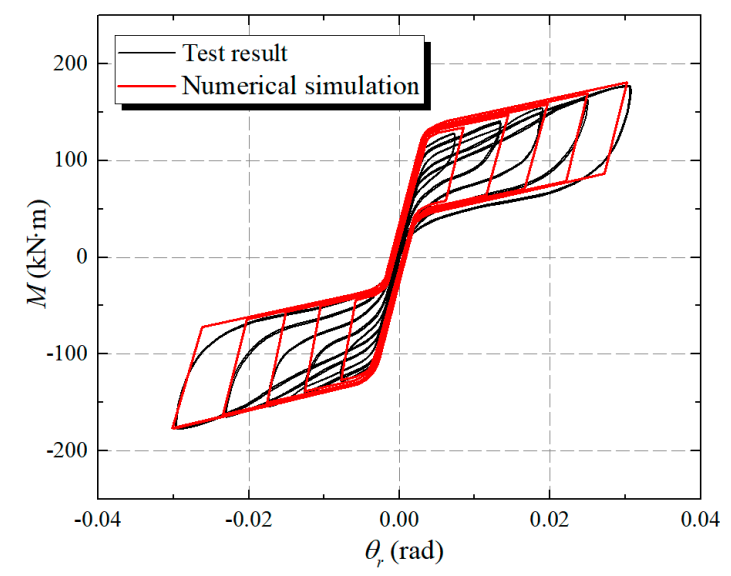

Figure 5. Comparisons of hysteretic behavior of numerical simulation and test results.

For the novel beam-column connection, the simplified hysteretic model of connection under cyclic loads is shown as Figure 6. As shown in Figure 6a, the theoretical hysteresis curve of the self-centering system taken by PT tendons is modelled with an idealized bilinear elastic spring. The analysis demonstrates hysteretic damper has ideally a much higher initial stiffness, it can be modelled as elastic plastic model. As shown in Figure 6b, the theoretical hysteresis curve of hysteretic dampers is an elastic-plastic model and the stiffness after yielding is zero. Hence, combined with the PT tendons and hysteretic dampers, the novel connection can be modelled as the bilinear elastic spring taken parallel with elastic plastic model. The theoretical hysteresis curve of novel hybrid joint is modelled as a typical double flag-shape hysteretic model. 


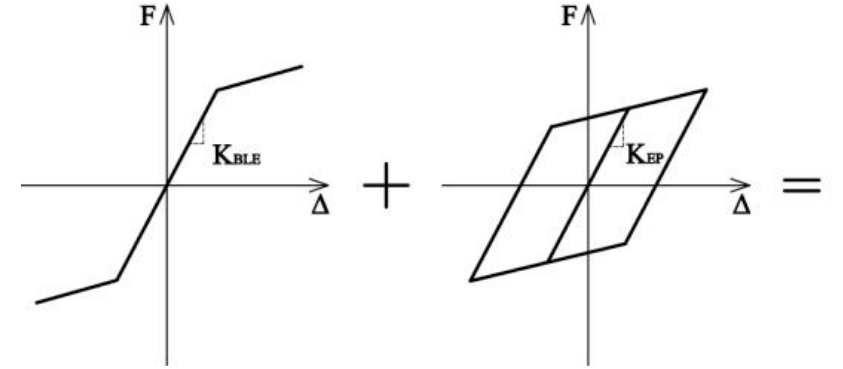

(a) Bilinear elastic spring model (b) Elastic-plastic model

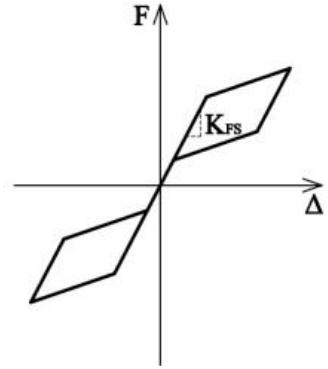

(c) Self-centering double flagshape model

Figure 6. Theoretical hysteretic model of the novel connection.

The mechanical principle of the novel hybrid joint with hysteretic dampers is defined as the gap opening and closing alternately under the near-fault earthquake wave actions. Figure 7 shows the mechanical principle of novel connection composites when it bears the positive moment under seismic actions-where $T$ is the resultant tension of all the unbonded tendons; $N_{t}$ and $N_{b}$ are the horizontal resultant forces of the upper and lower hysteretic dampers, when the beam-column joint subjected to the positive moment under the loadings, the upper hysteretic damper bear compressive force and the lower hysteretic damper bear tensile force; $V_{c}$ is the shear force taken by the fiction, reflecting the fictions caused by prestressed tendons and high strength bolts, respectively; $d_{1}$ is the distance between the top edge of the beam and the resultant point of PT tendons; $d_{t}$ and $d_{b}$ are the distances between the center point of the top and bottom hysteretic dampers and the top edge, respectively; The moment $M$ at the beam end includes the moment provided by unbonded tendons and the hysteretic dampers. $N_{P T}$ is the pre-pressure of PT tendons at the end beam, $\mu_{1}$ is the fiction coefficient of the beam-column interface, $N_{v}^{b}$ is the shear bearing capacity of single high strength bolt on the steel connection, the formula is:

$$
\begin{gathered}
M=T \cdot d_{1}-N_{t} \cdot d_{t}+N_{b} \cdot d_{b} \\
V_{c}=F_{f}=N_{P T} \times \mu_{1}+4 \times 2 \times N_{b}^{v} .
\end{gathered}
$$
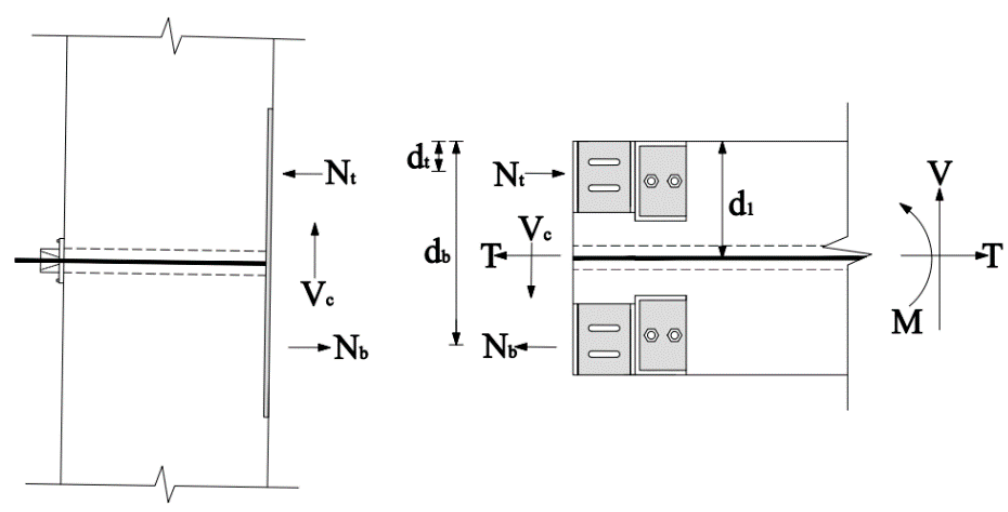

Figure 7. Theoretical hysteretic model of the novel SCPC connection.

The value of initial resultant force of unbonded tendons is $T_{0}$, when the bending moment at beam-column full contact interface exceed the critical opening moment $M_{I O}$ under the external load, the joint gap has opened, the formula of $M_{I O}$ is as follows:

$$
M_{I O}=T_{0} \cdot d_{1}-N_{t} \cdot d_{t}+N_{b} \cdot d_{b}
$$




\section{Structural Model}

\subsection{Prototype Frame Description}

To assess the seismic risk of the novel SCPC building under the near-fault earthquake waves, a five-story four-span prototype precast concrete frame with hysteretic dampers is designed for analysis. According to the design requirements of near-fault ground motion, the distance between the fault fracture surface and the site is within $15 \mathrm{~km}$. Near-fault earthquake waves are chosen from the PEER (Pacific Earthquake Engineering Research Center) record database, all the near-fault earthquake waves only considered the velocity pulse effect generated by the forward-directivity effect. Based on Chinese Standard GB 50010-2010 [28] and GB 50011-2010 [29], the site class of the prototype structures is defined as group II, the characteristic site period $T_{\mathrm{g}}$ is $0.40 \mathrm{~s}$ and the seismic intensity is categorized as 7.0. The original structural layout is regular, with dimensions of $24 \mathrm{~m} \times 24 \mathrm{~m}$. The total height of the frame is $32.8 \mathrm{~m}$ including $4.8 \mathrm{~m}$ for the first floor and $4.0 \mathrm{~m}$ for the upper floors. In the light of Chinese Standard Code [30], the dead load is $7.0 \mathrm{kN} / \mathrm{m}^{2}$ for the roof while it is $5.0 \mathrm{kN} / \mathrm{m}^{2}$ for other floor. Live loads for all the stories are $2.0 \mathrm{kN} / \mathrm{m}^{2}$. The calculation method of the representative value of gravity load of the novel frame is dead loads plus 0.5 times of live loads for the novel SCPC frame. The $P-\Delta$ effect of frame caused by gravity load is fully considered (the additional internal force and deformation produced by the precast concrete columns).

Figure $8 \mathrm{~b}$ displays the configuration and the reinforcing details. The grade of concrete strength is C40. The longitudinal reinforcement, stirrup and waist bars use HRB400, the corresponding elastic modulus is $2 \times 10^{5} \mathrm{MPa}$. The nominal sectional area of one unbonded tendon is $140 \mathrm{~mm}^{2}$ and six tendons are arranged in one duct. The yield strength of PT strands is $f_{\mathrm{py}}=1675 \mathrm{MPa}$ and the ultimate strength of PT strands is $f_{\mathrm{py}}=1860 \mathrm{MPa}$, the corresponding modulus of elasticity is $1.95 \times 10^{5} \mathrm{MPa}$. The steel used for the hysteretic dampers and steel plated are Q235 and Q335, the corresponding yield strengths are $235 \mathrm{MPa}$ and $335 \mathrm{MPa}$, respectively. For the beam, four longitudinal reinforcements of $18 \mathrm{~mm}$ are arranged at the bottom and the bottom, respectively. Two waist bars of $10 \mathrm{~mm}$ are arranged and tie bars of $10 \mathrm{~mm}$ are arranged with a spacing of $250 \mathrm{~mm}$. For the column, the diameters of longitudinal reinforcements arranged in the column cross sections are $20 \mathrm{~mm}$. The diameter of stirrups is $8 \mathrm{~mm}$ diameter and the spacing of the stirrups is $100 \mathrm{~mm}$ in the stirrup densification area. One duct use the polyvinyl chloride (PVC)pipe with the diameter of $40 \mathrm{~mm}$ arranged at the beam center and four unbonded tendons do not grout in the duct. The configuration of the steel connector is shown in Figure 8c. The steel connectors are welded between the steel plate and the hysteretic dampers and bolted on the two sides of the beam using high strength friction bolts to limit the dampers' displacements. For the hysteretic dampers and steel connectors, the thickness of all the steel plates is $10 \mathrm{~mm}$.

This study uses performance-based seismic design methods to assess the seismic performance of a novel structure from elasticity to partial or overall collapse. According to the Federal Emergency Management Agency (FEMA)356 and characteristics of the novel SCPC frame, the design approach uses two performance state limits-Immediate occupancy (IO) and Repairable (RE) [31]. In addition, two seismic levels are considered-the design basis earthquake (DBE) and the maximum considered earthquake (MCE), whose earthquake return period are 475 years and 2475 years, respectively. The maximum horizontal seismic influence coefficient at the DBE level is about half of that at the MCE level. To assess the damage degree of the novel frame accurately, the displacement evaluation index, including the peak inter-story drift ratio and the peak residual inter-story drift ratio, are used. Therefore, the design target of structural limit states at two performance levels displays as follows.

Under the DBE earthquake level, the novel frame must fit the IO limit state. The structure damage level is very small; it can be reused without repair. When the beam-column connection gap is open, the concrete of the connection is in a state of eliminating pressure, the stress at the beam end declines to zero under the seismic actions. Minor hairline cracking appeared in a few places in precast columns 
and slight yielding phenomena occurred in the column. The allowable peak inter-story drift ratio cannot exceed in $1.0 \%$ and the peak residual inter-story drift ratio cannot exceed in $0.2 \%$ [30].
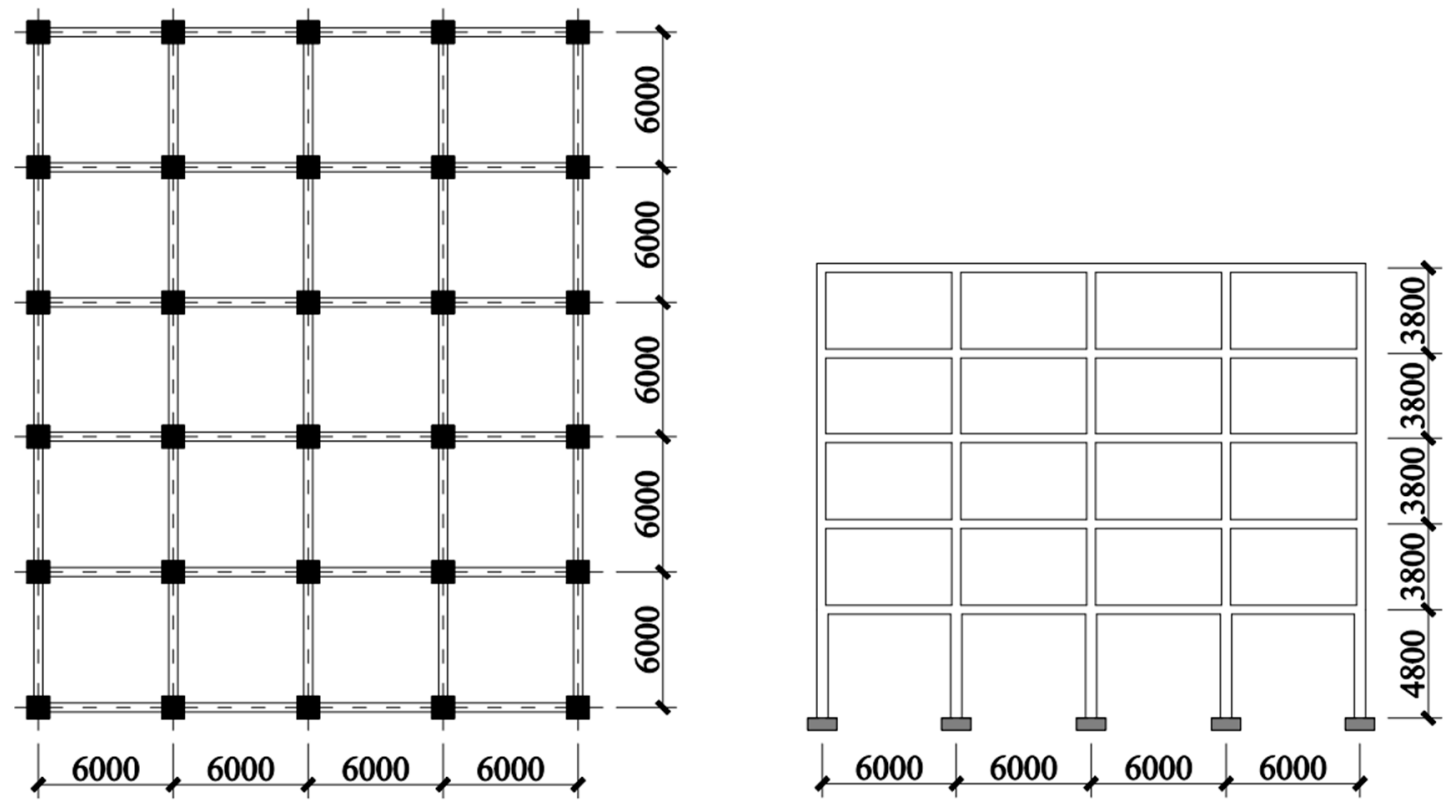

(a) Layout plan and elevation of the designed structure
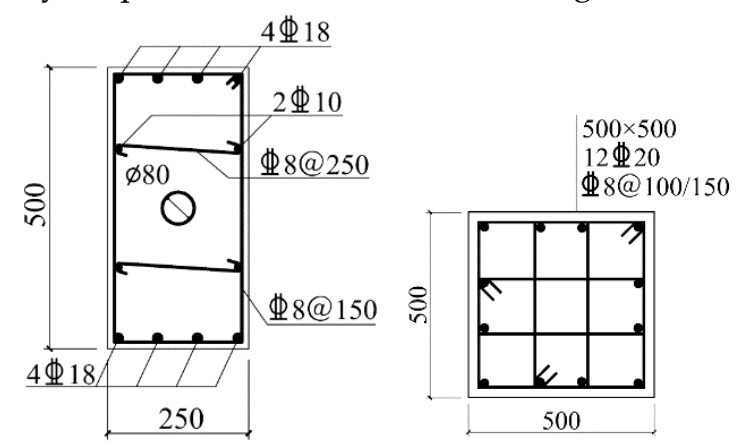

(b) Configuration and reinforcement details of beam and column

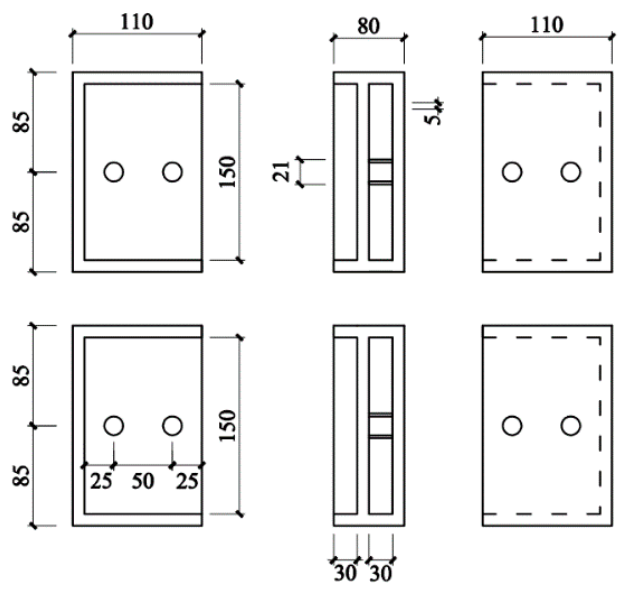

(c) Configuration of steel connector

Figure 8. Details dimensions of the prototype structure and steel connector (mm). 
Under the MCE earthquake level, the novel frame must fit the RE limit state. The extensive cracks and plastic hinges are appeared in the column elements. Minimal yielding at the column bases is allowed, PT tendons are always elastic and do not yield. If the PT tendons yield, the connection will lose the restoring function and generate large residual deformation. The overall damage level is moderate and can be reused after repairing. The allowable peak inter-story drift ratio cannot exceed $2 \%$ and the residual story drift ratios cannot exceed $0.5 \%$. The analysis from the existing earthquake damage reports shows-if the peak residual inter-story drift ratio exceed $0.5 \%$, it does not make sense to repair the damage components from the viewpoint of economic efficiency [31].

\subsection{Selected Near-Fault Ground Motions}

The near-fault earthquake waves usually mean the distance between the rupture fault and building site is less than $20 \mathrm{~km}$, epicenter intensity is less than 6.5 degrees and peak acceleration is more than $0.15 \mathrm{~g}$ [32]. To accurately assess the seismic performance and energy consumption capacity of the novel SCPC frame, 21 near-fault earthquake waves which are collected in the 12 earthquakes from PEER (Pacific Earthquake Engineering Research Center) record database were chosen for the elastoplastic dynamic analysis. The substantial observed seismic data demonstrate the near-fault ground motions are obviously different from the far-field ground motions. Because the rupture is close to building site, high-frequency damping is minimal and the velocity and displacement time-history of near-fault earthquake waves have the large amplitude and short duration. However, the velocity pulse effect of the near-fault earthquake waves means forward-directional effect and fling step effect. The directional effect can be divided into forward directional effect, backward directional effect and neutral directional effect and directional effect mainly refers to forward directional effect. Forward directional effect is the main cause of pulse effect and the damage of structures will be aggravated by forward-directional effect. Directional effect can make seismic energy accumulate in a short time and cause impact ground motion, which is reflected in large peak value, obvious pulse waveform and short duration of earthquake on time-history curve.

The fling step effect is generated by the relative movement of two fault rupture, which raises a single direction half pulse or one side pulse form in the velocity time-history curve and generates residual deformation on the ground [33]. Since the earthquake wave records in the PEER database are processed, the displacement is zero at the end of the record, so there is no record reflecting the slip effect. At present, structural damage caused by the fling step effect can only be solved by the method of seismic conceptual design. Near-fault earthquake waves usually only considered the forward directivity effect. The information of 21 ground motions is listed in Table 1, which includes the peak ground acceleration (PGA), peak ground velocity (PGV), peak ground displacement (PGD). The distance from the rupture fault to the structure site is less than $11 \mathrm{~km}$ and magnitudes $M_{w}$ ranges from 6.19 to 7.51. The ground acceleration, displacement and velocity time-histories of near-fault ground motions KJM090 and H-E07230 are shown in Figure 9. The adjusted peak ground acceleration of each near-fault ground motion is equivalent to the two seismic levels. From the aforementioned research, the Rayleigh-type 3\% damping ratios of the novel SCPC frame is based on the first and second modes of the vibration [34]. The corresponding acceleration response spectrum of each near-fault earthquake wave is shown in Figure 10 and the mean spectrum and the target spectrum are also shown in Figure 10.

Table 1. Information of selected near-fault ground motions.

\begin{tabular}{cccccccc}
\hline Number & Seismic Name & $\begin{array}{c}\text { Ground } \\
\text { Motion Name }\end{array}$ & $\begin{array}{c}\text { Magnitude } \\
\mathbf{( M w )}\end{array}$ & $\begin{array}{c}\text { Distance } \\
\mathbf{( k m )}\end{array}$ & PGA (g) & $\begin{array}{c}\text { PGV } \\
(\mathbf{c m} / \mathbf{s})\end{array}$ & PGD (cm) \\
\hline 1 & Kocaeli, Turkey 1999 & GBZ000 & 7.51 & 10.92 & 0.244 & 50.3 & 42.74 \\
\hline 2 & Kobe 1995 & TAZ000 & 6.9 & 0.27 & 0.693 & 68.3 & 26.65 \\
\hline 3 & Kobe 1995 & TAZ090 & 6.9 & 0.27 & 0.694 & 85.3 & 16.75 \\
\hline 4 & Kobe 1995 & KJM000 & 6.9 & 0.96 & 0.821 & 81.3 & 17.68 \\
\hline
\end{tabular}


Table 1. Cont

\begin{tabular}{cccccccc}
\hline \multirow{2}{*}{ Number } & Seismic Name & $\begin{array}{c}\text { Ground } \\
\text { Motion Name }\end{array}$ & $\begin{array}{c}\text { Magnitude } \\
(\mathbf{M w})\end{array}$ & $\begin{array}{c}\text { Distance } \\
\mathbf{( k m})\end{array}$ & PGA (g) & $\begin{array}{c}\text { PGV } \\
(\mathbf{c m} / \mathbf{s})\end{array}$ & PGD (cm) \\
\hline 5 & Kobe 1995 & KJM090 & 6.9 & 0.96 & 0.599 & 74.3 & 19.95 \\
\hline 6 & Loma Prieta 1989 & LGP000 & 6.93 & 3.88 & 0.563 & 94.8 & 41.18 \\
\hline 7 & Loma Prieta 1989 & LGP090 & 6.93 & 3.88 & 0.605 & 51 & 11.5 \\
\hline 8 & Morgan Hill 1984 & HVR240 & 6.19 & 3.48 & 0.312 & 39.4 & 7.66 \\
\hline 9 & Imperial Valley-06 1979 & H-E04230 & 6.53 & 7.05 & 0.36 & 76.6 & 59.02 \\
\hline 10 & Imperial Valley-06 1982 & H-E07230 & 6.53 & 0.56 & 0.463 & 109.3 & 44.74 \\
\hline 11 & Cape Mendocino 1992 & CPM000 & 7.01 & 6.96 & 1.497 & 127.4 & 41.01 \\
\hline 12 & Cape Mendocino 1992 & CPM090 & 7.01 & 6.96 & 1.039 & 42 & 12.39 \\
\hline 13 & Cape Mendocino 1992 & PET000 & 7.01 & 8.18 & 0.59 & 48.4 & 21.74 \\
\hline 14 & Cape Mendocino 1992 & PET090 & 7.01 & 8.18 & 0.662 & 89.7 & 29.55 \\
\hline 15 & Duzce, Turkey 1999 & DZC270 & 7.14 & 6.58 & 0.535 & 83.5 & 51.59 \\
\hline 16 & Northridge 1994 & JEN022 & 6.69 & 5.43 & 0.424 & 106.2 & 43.06 \\
\hline 17 & Northridge 1994 & NWH360 & 6.69 & 5.92 & 0.59 & 97.2 & 38.05 \\
\hline 18 & Northridge 1994 & RRS228 & 6.69 & 6.5 & 0.838 & 166.1 & 28.7 \\
\hline 19 & Northridge 1994 & SCS142 & 6.7 & 5.35 & 0.897 & 102.8 & 46.99 \\
\hline 20 & Northridge 1994 & SPV270 & 6.7 & 8.44 & 0.753 & 84.8 & 18.68 \\
\hline 21 & Northridge 1994 & SYL360 & 6.7 & 5.3 & 0.843 & 129.6 & 32.68 \\
\hline
\end{tabular}

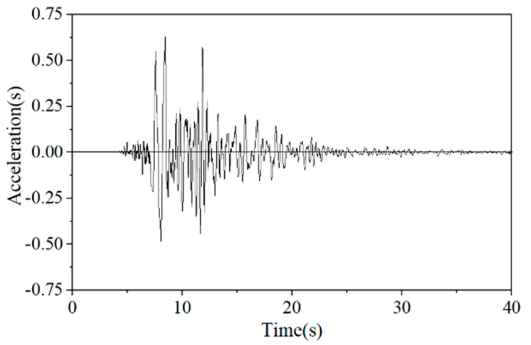

(a) Ground acceleration time-history of KJM090

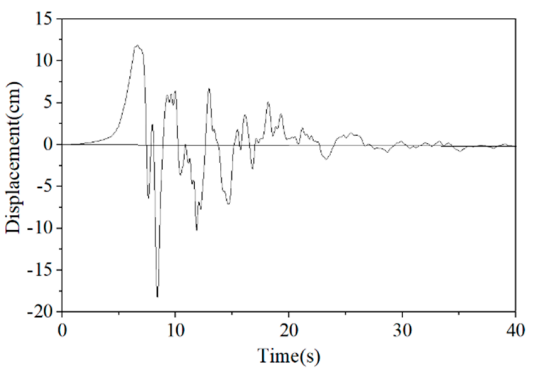

(c) Ground displacement time-history of KIM090

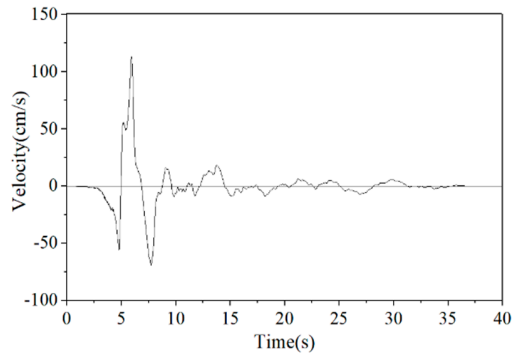

(e) Ground velocity time-history of H-E07230

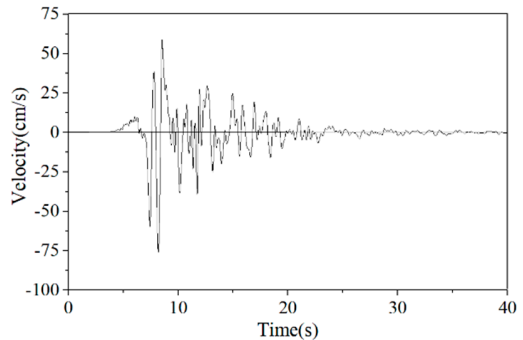

(b) Ground velocity time-history of KJM090

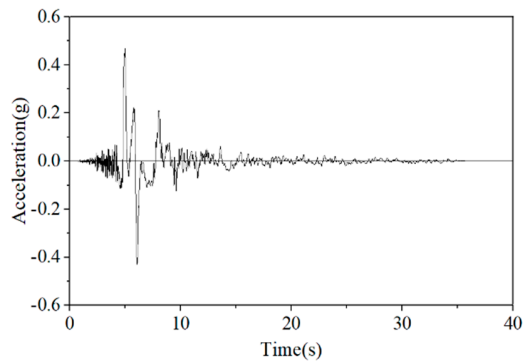

(d) Ground acceleration time-history of H-E07230

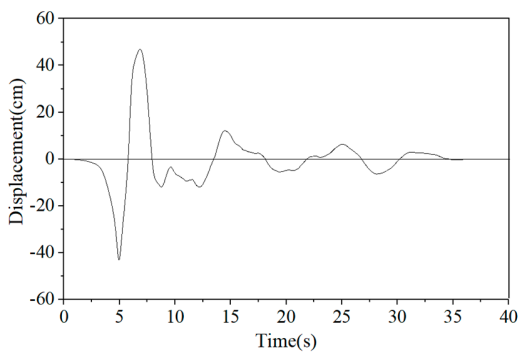

(f) Ground displacement time-history of H-E07230

Figure 9. The time-histories of near-fault earthquake waves KJM090 and H-E07230. 


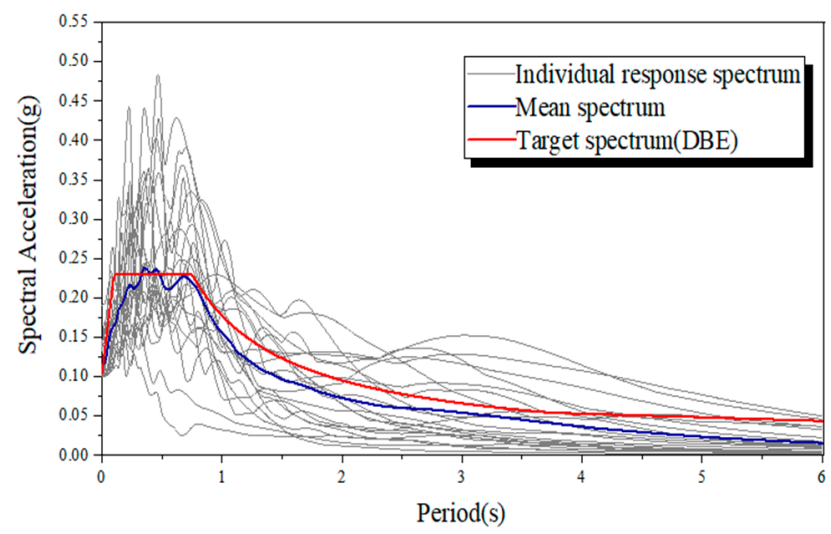

(a) DBE level spectrum

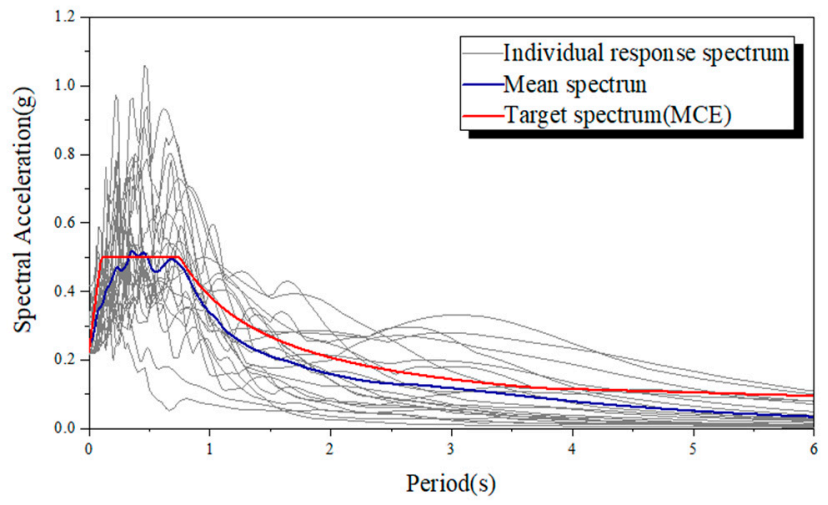

(b) MCE level spectrum

Figure 10. Acceleration response spectrum of near-fault earthquake waves.

\section{Finite Element Study of Novel SCPC Joint}

To evaluate the seismic behaviors of the novel SCPC frame, a 5-story prototype building is modelled as a 2D plane numerical model using the OpenSees software and the nonlinear time-history analysis was performed [35]. When the gap-opening occurred under the load, the sections do not fit the plane section assumption; the mechanical behavior of the novel connection is complex. The connection analysis model is based on the following basic assumptions-(1) the joint only considers the load in the plane and has the deformation in the plane without torsion; (2) shear failure of beam and column can be avoided through the reasonable stirrup arrangement; (3) the hysteretic dampers, beam and column do not slip in the whole loading process.

Figure 11 displays the accurate finite element model of the novel SCPC joint, which mainly consists of nonlinear beam column elements, zero length elements and truss elements. Two different types of constitutive relationships were used for concrete materials of the connection-(1) unconfined concrete in protective cover (without stirrup restraint); (2) concrete in core area (stirrup restraint). They are simulated by Concrete 01 material model consisting of three parts-nonlinear ascending section, linear descent section and horizontal section [36]. Concrete 01 material model do not consider the tensile strength of concrete and the concrete crushing, residual strength is accounted for. Considering the amplification effect of stirrup on confined concrete, there are various confined concrete model to calculate the confined concrete strength enhancement for both normal-strength and high-strength concrete [37-40]. The amplification factor of compressive strength and strain is 0.2 according to the parameters such as stirrup ratio and stirrup spacing. The steel fiber including steel bars and PT tendons are assigned to the Steel 02 material model, which are based on Giuffre-Menegotto-Pinto model [41]. Steel 02 material model has an initial stress, the Bauschinger effect and isotropic reinforcement effect can be reflected in the cyclic loading. As shown in Figure 12, all the beams and columns are modelled by 
Nonlinear Beam Column element, which consider the spread of plasticity along the element through a number of integration points. Each element is divided by many fiber cross sections by integration points and each fiber was given a uniaxial stress-strain relationship. The hysteretic dampers arranged at the upper and lower at the beam-column interface are simulated by zero length spring elements between node 14, 15 and 16, 17 [42]. The gap opening and closing behavior is also modelled by two pairs of zero length elements. The element is assigned to Elastic PP Gap material model with compression-only material properties. Although the gap is opened, the hysteretic dampers and beam-column interface do not slip. When the gap is opened, the sum of horizontal relative displacements of the upper and lower rotation points is $\Delta_{g a p}$, the vertical distance of the two points is $h$, so the relative connection rotation is $\theta_{r}=\Delta_{\text {gap }} / h$. Three degrees of freedom of node 15 and node 17 are coupled with node 9 , three degrees of freedom of node 14 and node 16 are coupled with node 4 and node 3 . The rigid link elements (which is used to construct a single multipoint constraint) are selected to reflect the coupling characteristics between the above nodes. In the modelling of the beam-column interface, the effect of critical region length was considered. The critical region length is the distance between node 9 and node 10, where the most severe damage will take place [43,44]. The constitutive relationships of the concrete and steel materials model in the critical region are assigned to compression only material properties in the critical region. Truss element model between node 7 and node 12 are used to simulate the unbonded tendons at the beam center. Steel 02 material model with initial stress is adopted to simulate the constitutive relationship of the truss element due to prestressed tendons have the initial force. Truss element only consider the axial force and axial deformation, ignore geometric distortion in the vertical direction. In addition, the three degrees of node 10 and node 11 are coupled with node 13 respectively and use the equal Degree of freedom (DOF)constraints [45].

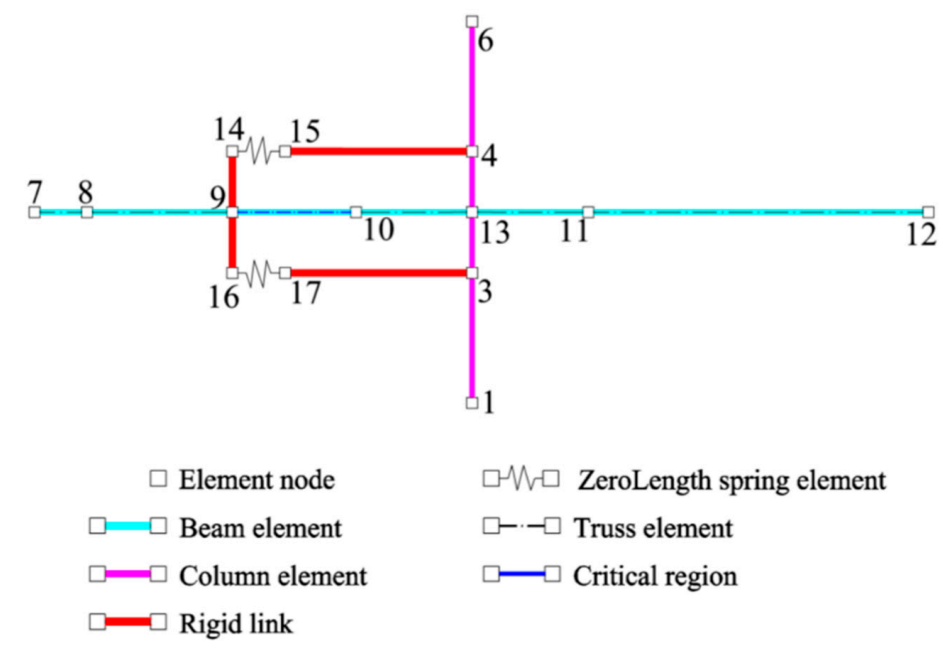

Figure 11. Analytical connection model of the novel S CPC frame with Opensees.

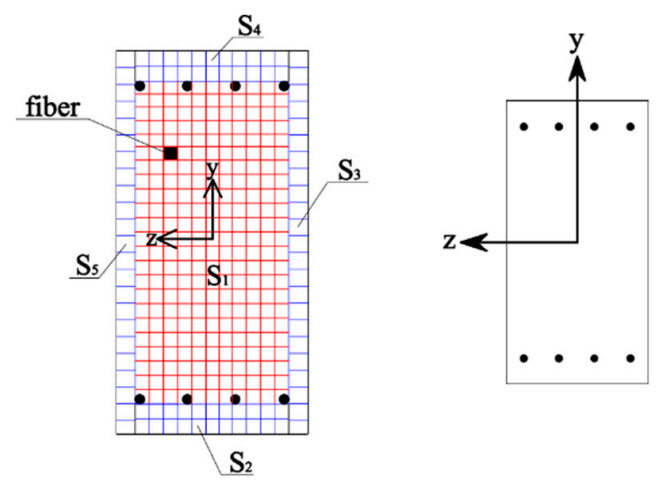

Figure 12. The cross section of Nonlinear Beam Column elements. 
The finite element model method of the whole new SCPC frame with hysteretic dampers is the same as the model method of the new SCPC frame beam-column joint described in the above study. The model analyze is firstly conducted and the fundamental period of the novel SCPC frame is $1.04 \mathrm{~s}$.

\section{Seismic Risk Assessment of Novel SCPC Frame}

\subsection{Overall Responses to Near-Fault Earthquakes}

Nonlinear time-history analysis is applied to the five-story four-span novel SCPC frame numerical model at the DBE and MCE earthquake levels using OpenSees software. The horizontal seismic influence coefficient of the prototype frame at the DBE and MCE levels are 0.117 and 0.234 calculated by the seismic intensity, site category, design earthquake grouping, the fundamental period and damping ratio according to Chinese Standard Code [29]. The gravity load of each story is evenly distributed at the central node of the core area of the beam-column connection. In order to calculate the residual deformations of the novel frame, $20 \mathrm{~s}$ last-time free vibration analysis of the structure continued after applying each near-fault ground motion action. From the aforementioned analysis results, the peak inter-story drift ratios and peak residual inter-story drift ratios are selected as the main evaluation index to define IO and RE limit state under the near-fault earthquake wave loadings.

Figure 13 displays the top floor displacement time-history curves of the near-fault earthquake waves NO.10-LGP090, NO.13-H-E04230, NO.18-CPM090 respectively. The peak value of top floor displacements are $23.5 \mathrm{~mm}, 20.8 \mathrm{~mm}$ and $32.4 \mathrm{~mm}$ under the DBE level and the peak value of top floor displacements are $54.2 \mathrm{~mm}, 46.7 \mathrm{~mm}$ and $69.8 \mathrm{~mm}$ under MCE level, respectively. The peak value of top floor displacements occur about in $11 \mathrm{~s}, 7 \mathrm{~s}$ and $4 \mathrm{~s}$ for the above three waves, which indicates the displacement responses of the frame are relatively large at the beginning and the displacements reduce significantly because of the self-centering capability for the novel SCPC frame. Hence, the final residual displacements for the novel frame are minimal under each ground motion. The final residual top floor displacements for the precast frame are $0.23 \mathrm{~mm}, 0.15 \mathrm{~mm}$ and $0.41 \mathrm{~mm}$ for NO.10-LGP090, NO.13-H-E04230, NO.18-CPM090 under the MCE level, respectively. The maximum top floor displacements, the times the maximum response occurs and the residual top displacements under 21 earthquake waves are all listed on Table 2. The above analysis results present the novel SCPC frame has greater lateral stiffness and good self-centering capability, the top floor displacement responses are in a reasonable range under DEB and MCE levels.

Table 2. Maximum top floor displacements under 21 ground motions.

\begin{tabular}{|c|c|c|c|c|c|c|}
\hline Number & $\begin{array}{c}\text { Ground Motion } \\
\text { Name }\end{array}$ & $\begin{array}{c}\text { Max Top Displacement } \\
\text { (DBE) }(\mathrm{mm}) \\
\mathrm{mm}((\mathrm{mm})\end{array}$ & Time Occur (s) & $\begin{array}{l}\text { Max Top } \\
\text { Displacement } \\
\text { (MCE) }(\mathrm{mm})\end{array}$ & Time Occur (s) & $\begin{array}{c}\text { Residual Top } \\
\text { Displacements } \\
(\mathrm{mm})\end{array}$ \\
\hline 1 & GBZ000 & 25.1 & 7.2 & 47.3 & 7.2 & 0.23 \\
\hline 2 & TAZ000 & 31.8 & 5.9 & 70.5 & 5.44 & 0.40 \\
\hline 3 & TAZ090 & 34.6 & 6.38 & 75.1 & 5.98 & 0.42 \\
\hline 4 & KJM000 & 51.8 & 3.38 & 112.4 & 3.5 & 0.51 \\
\hline 5 & KJM090 & 42.4 & 9.84 & 90.2 & 9.92 & 0.45 \\
\hline 6 & LGP000 & 30.2 & 12.28 & 68.3 & 11.84 & 0.38 \\
\hline 7 & LGP090 & 23.5 & 11.1 & 54.2 & 11.14 & 0.23 \\
\hline 8 & HVR240 & 33.5 & 13.12 & 73.7 & 13.2 & 0.42 \\
\hline 9 & H-E04230 & 20.8 & 7.8 & 46.7 & 7.84 & 0.15 \\
\hline 10 & H-E07230 & 45.4 & 7.38 & 95.3 & 7.56 & 0.47 \\
\hline 11 & СРМ000 & 56.0 & 8.08 & 113.2 & 8.12 & 0.53 \\
\hline 12 & СРМ090 & 32.4 & 3.6 & 69.8 & 3.6 & 0.41 \\
\hline 13 & PET000 & 36.3 & 2.96 & 85.1 & 2.98 & 0.43 \\
\hline 14 & PET090 & 22.1 & 3.08 & 46.2 & 3.1 & 0.18 \\
\hline 15 & DZC270 & 25.8 & 3.72 & 55.1 & 3.72 & 0.22 \\
\hline 16 & JEN022 & 21.4 & 3.6 & 45.2 & 3.6 & 0.16 \\
\hline 17 & NWH360 & 31.3 & 6.92 & 57.2 & 6.98 & 0.39 \\
\hline 18 & RRS228 & 35.3 & 7.06 & 81.7 & 4 & 0.41 \\
\hline 19 & SCS142 & 44.3 & 5.82 & 91.2 & 5.86 & 0.47 \\
\hline 20 & SPV270 & 38.5 & 3.5 & 85.5 & 3 & 0.44 \\
\hline 21 & SYL360 & 25.3 & 7.3 & 55.1 & 7.4 & 0.23 \\
\hline
\end{tabular}



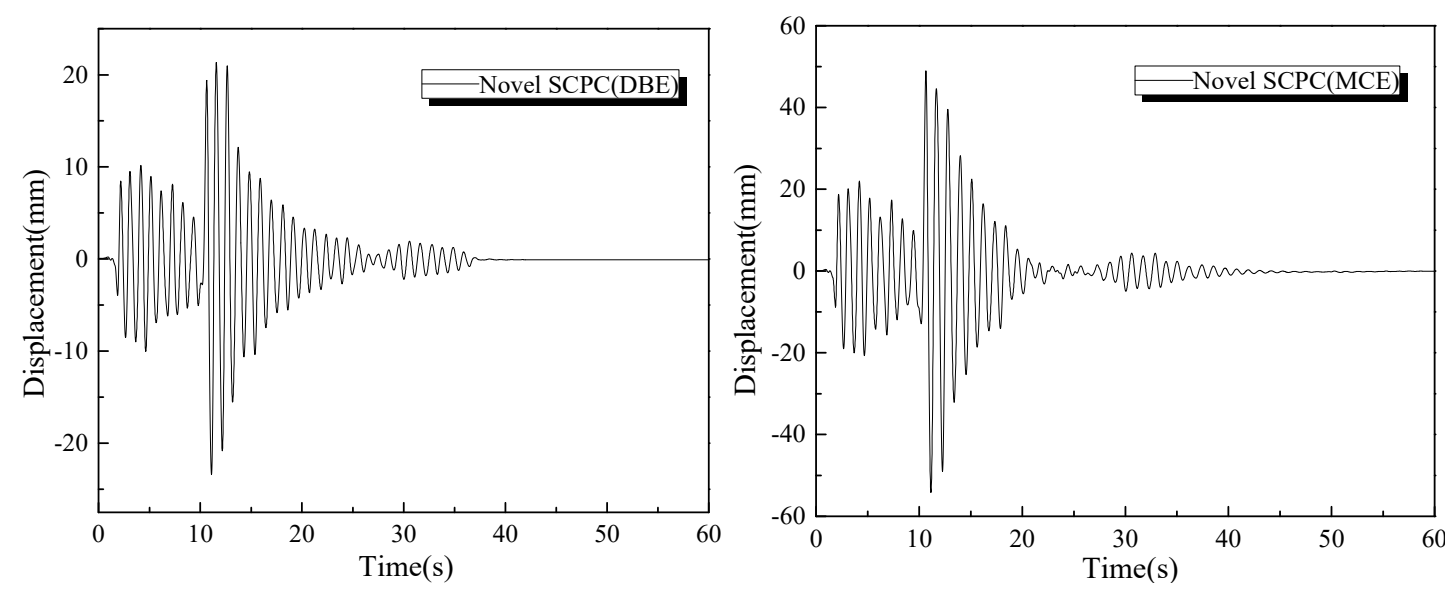

(a) The top floor displacement-time history curves of near-fault ground motion LGP090
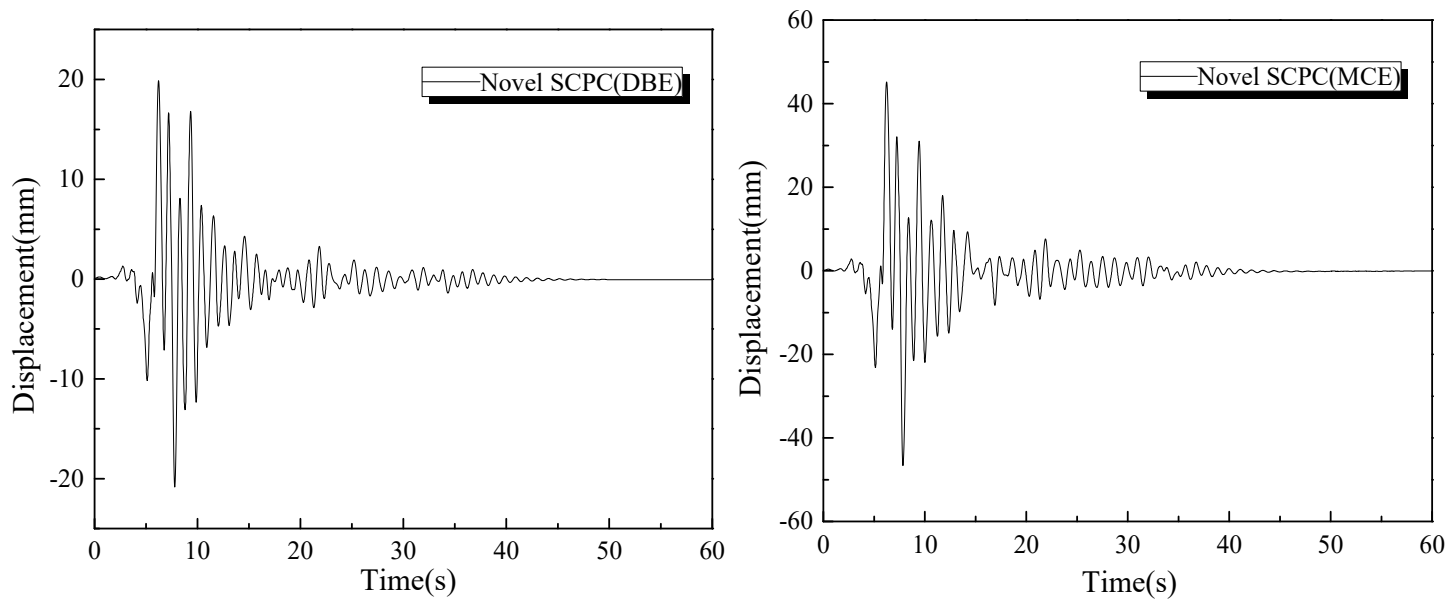

(b) The top floor displacement-time history curves of near-fault ground motion H-E04230
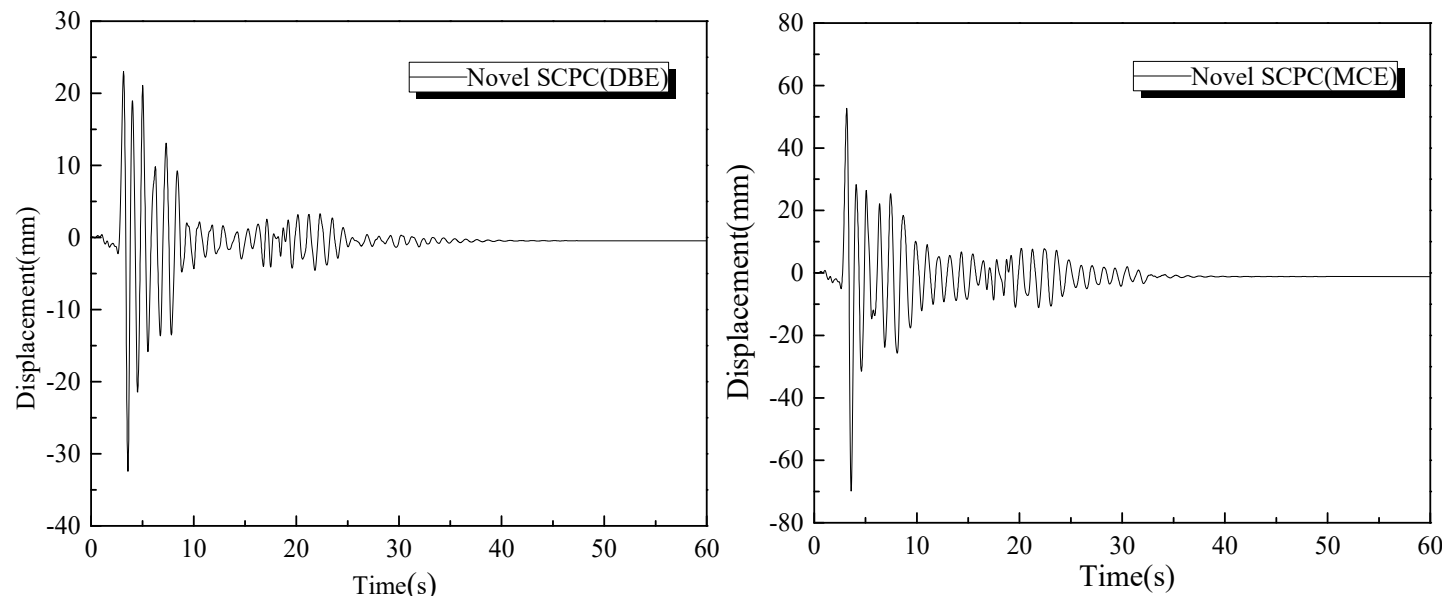

(c) The top floor displacement-time history curves of near-fault ground motion CPM090

Figure 13. Time-history curves of top floor displacement-time history curves under design basis earthquake (DBE) and maximum considered earthquake (MCE).

The peak inter-story drift ratios for each earthquake wave and for each story subjected to DBE and MCE levels under the near-fault ground motions are displayed in Figure 14. The maximum seismic 
responses for each floor, such as inter-story drift ratio, residual inter-story ratio, inter-story shear force and connection relative rotation, are the average values of the peak responses under 21 earthquake waves. The peak inter-story drift ratios of the novel frame are $0.72 \%$ and $2.03 \%$ corresponding for 21 near-fault earthquake waves at the DBE and MCE levels, respectively. The mean value of peak inter-story drift ratios of the frame for 21 earthquake waves are $0.34 \%$ and $0.81 \%$ subjected to the two levels, which are below the limiting requirements. The peak inter-story drift ratios for each story happen on the second story under the two seismic levels. The maximum responses from the third and the fifth story are equal to $0.29 \%, 0.22 \%, 0.15 \%$ at the DBE level and $0.68 \%, 0.51 \%$ and $0.29 \%$ at the MCE level, respectively. The peak inter-story drift ratios for each story at MCE level are about twice that at DBE level. It indicates that the degree of gap-opening at the beam-column interface has significantly increased at the MCE level, the bending stiffness of the connection has reduced.

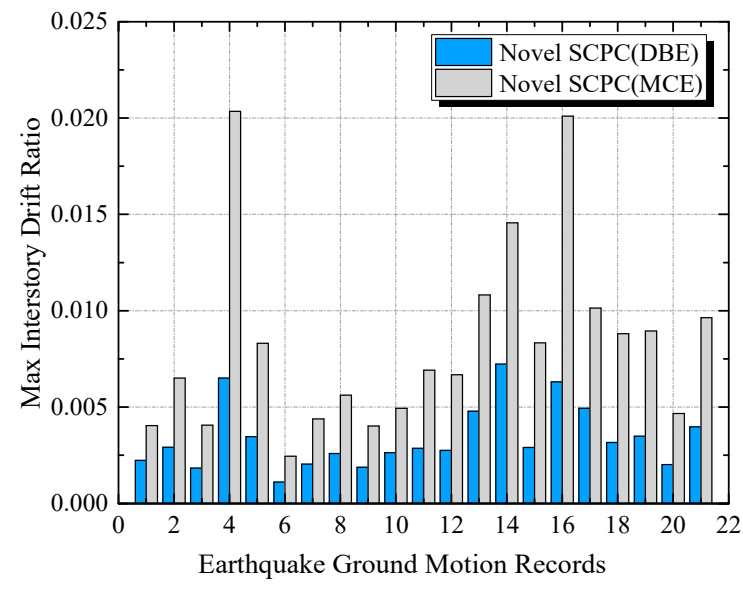

(a) for each ground motion at DBE and MCE

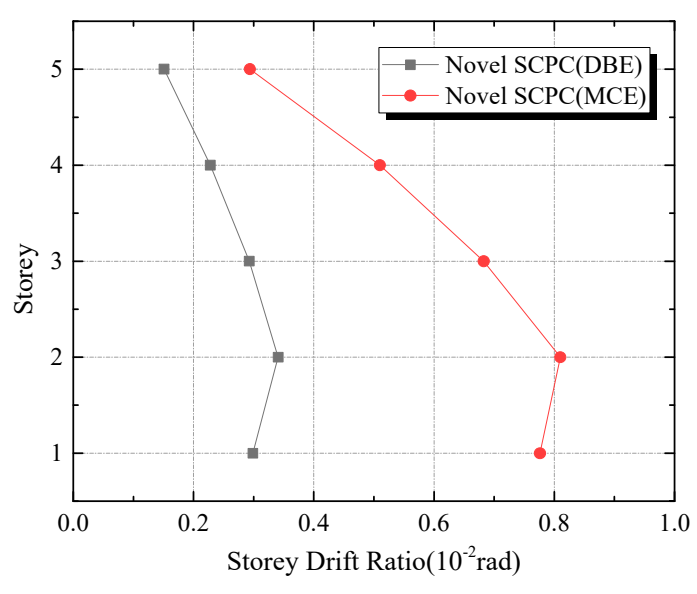

(b) for each story at DBE and MCE

Figure 14. Maximum inter-story drift ratio for each near-fault ground motion and for each story.

Figure 15 shows the maximum residual inter-story ratio for each story at the DBE and MCE levels for the 21 near-fault earthquake waves. The peak residual inter-story drift ratios of the novel frame for all the stories are minimal, satisfy the limiting value which cannot exceed in $0.2 \%$ for IO limit state and $0.5 \%$ for RE limit state. The maximum residual inter-story ratios both occur on the first floor, which are only $3.85 \times 10^{-5} \mathrm{rad}$ and $1.87 \times 10^{-4} \mathrm{rad}$ at DBE and MCE level and the peak residual inter-story drift ratios of the above stories are similar and close to zero. It indicates the novel frame with hysteretic dampers still has excellent self-centering ability under the near-fault seismic wave actions.

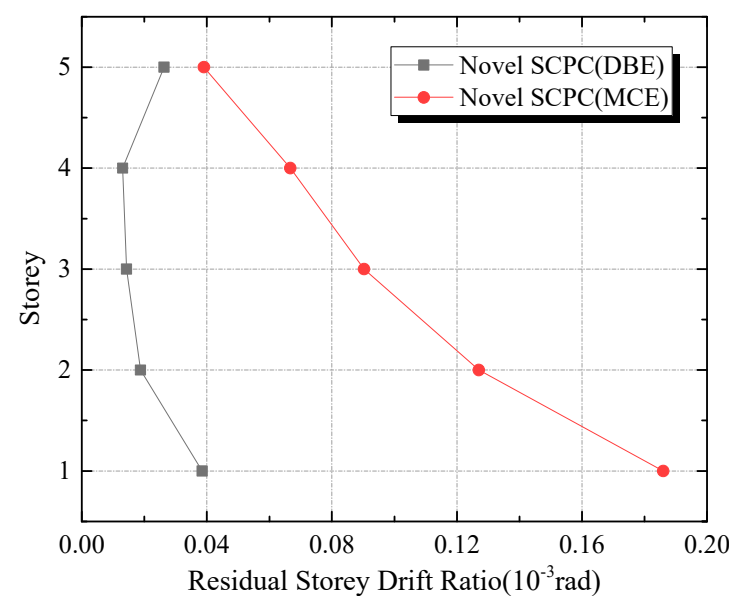

Figure 15. Maximum residual inter-story drift ratio for each story. 
Figure $16 \mathrm{a}$ and $\mathrm{b}$ show the maximum inter-story shear force for each earthquake wave and for each story under the two levels for the 21 near-fault earthquake waves, respectively. The peak inter-story shear force are $631 \mathrm{kN}$ and $930 \mathrm{kN}$ corresponding to 21 earthquake waves at the DBE and MCE levels, respectively. The peak inter-story shear force for each story have occurred on the first story under the two levels. The maximum responses of the first story are $365 \mathrm{kN}$ and $650 \mathrm{kN}$ at the DBE and MCE levels, respectively and the disparities between them are less than twice. From the second floor to the fifth floor, the inter-story shear forces decrease gradually. The maximum responses form the second to fifth story are $343 \mathrm{kN}, 302 \mathrm{kN}, 256 \mathrm{kN}$ and $202 \mathrm{kN}$ under the DBE level and $562 \mathrm{kN}, 515 \mathrm{kN}, 401 \mathrm{kN}$ and $305 \mathrm{kN}$ under the MCE level, respectively. It indicates that the novel SCPC frame has sufficient lateral stiffness to undertake more loadings.

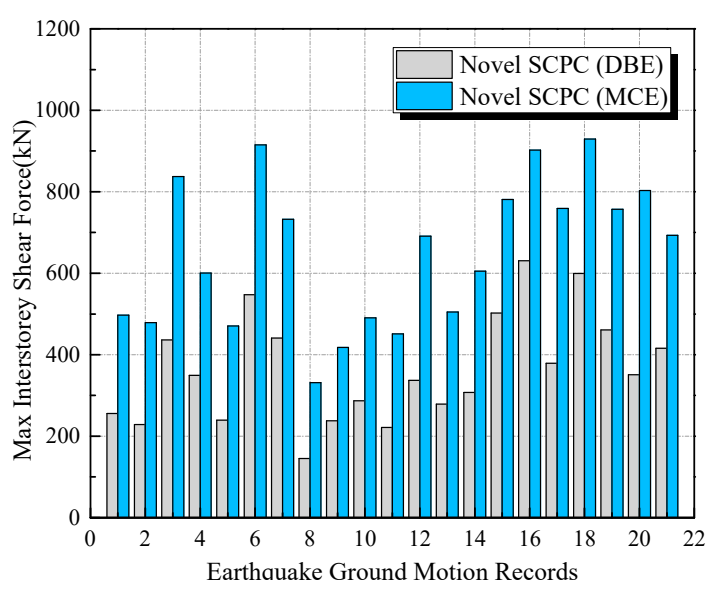

(a) for each ground motion at DBE and MCE

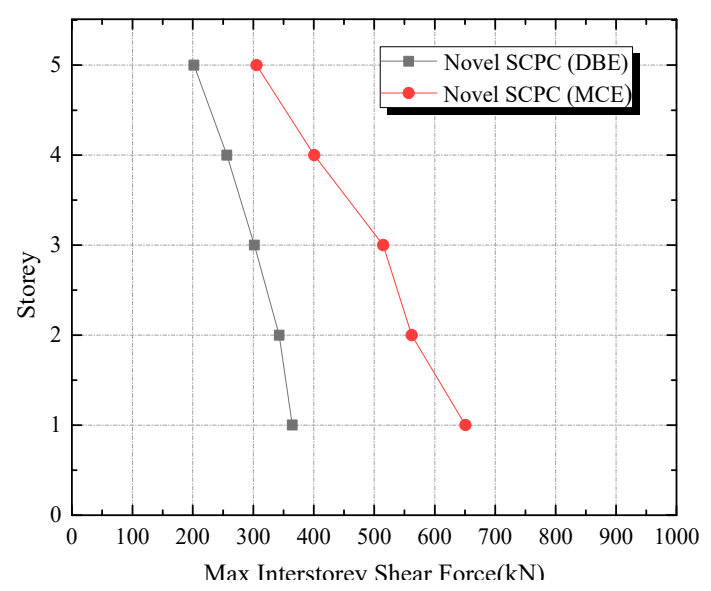

(b) for each story at DBE and MCE

Figure 16. Maximum inter-story shear force for each near-fault ground motion and for each story.

Figure 17 displays the maximum connection relative rotation and the maximum standard PT tendons force for each story at the two seismic levels dunder the near-fault earthquake waves loading. $T_{N}$ defines as the standardized PT force, which is the ratio of PT force and PT yielding force $T_{y}$. Figure 17a indicates-the maximum connection relative rotation of the novel SCPC frame for each story is minimal. The peak value is $8.5 \times 10^{-4} \mathrm{rad}$ for the second floor under the DBE level and it means the beam-column interface do not open basically. The peak connection relative rotations increase obviously at the MCE level, the peak value is $3 \times 10^{-3} \mathrm{rad}$ occurred at the first floor. The maximum connection rotations decrease gradually and the value of the top floor is only $1.3 \times 10^{-3} \mathrm{rad}$. Figure $17 \mathrm{~b}$ indicates-the maximum PT tendons force is relatively small for each story under DBE level and increase significantly at the MCE seismic level. In order to avoid great residual displacement in the core zones of beam-column connection, the PT tendons should not yield. The peak values of the maximum standardized PT tendon forces are about 0.48 times and 0.6 times of the yielding tendon force at the DBE and MCE levels. From the analysis results, unbonded tendons force for each story is in the elastic stage, far from reaching its yield strength under the MCE level.

The hysteretic relationship of the beam end moment $M$ and connection relative rotation $\theta_{r}$ is the important index to assess the energy consumption characteristics of the novel SCPC structure. Figure 18 shows the $M-\theta_{r}$ curve of the joint for the earthquake wave KJM090 loading under the MCE level. The joint is located in the right of the second span of the second story. The figure shows the peak connection rotation is only 0.003 and the peak connection moment is $620 \mathrm{KN}$. In addition, the beam end $M-\theta_{r}$ relation curves of the novel joint in the middle column is stable and shows typical double-flag shape. This sufficiently indicates that the novel frame joint with hysteretic dampers has effective energy consumption and self-recovering characteristics. 


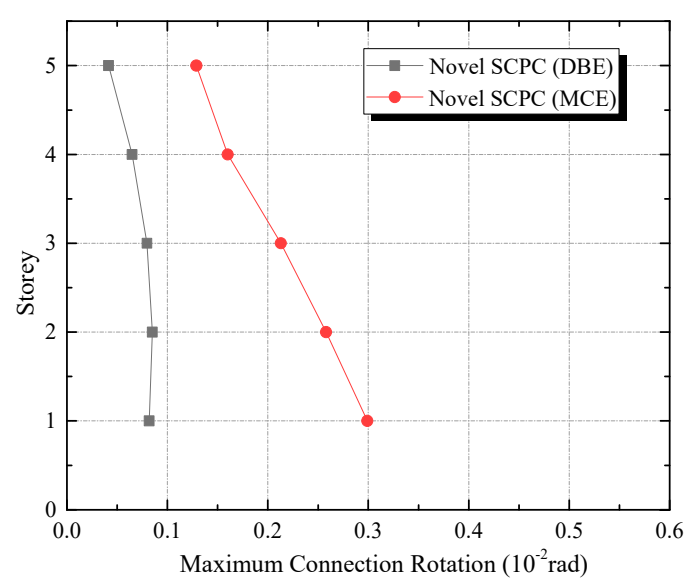

(a)Max connection rotation for each story

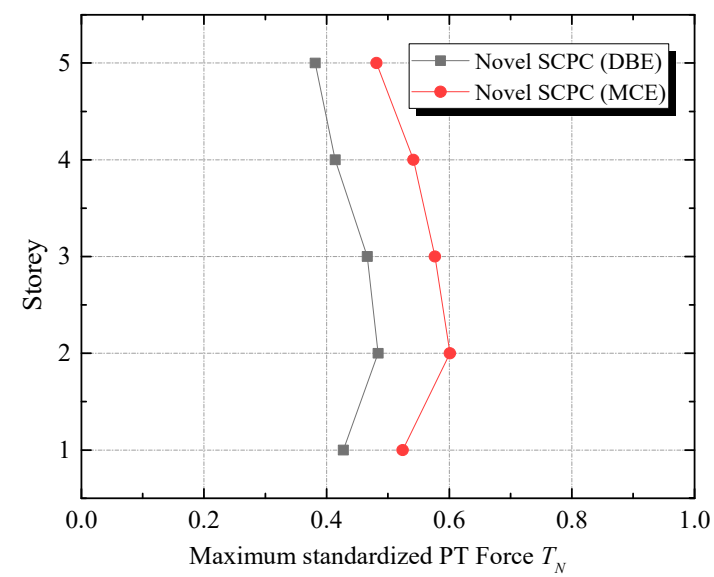

(b) Max standardized PT force for each story

Figure 17. Maximum connection rotation and standardized PT force for each story.

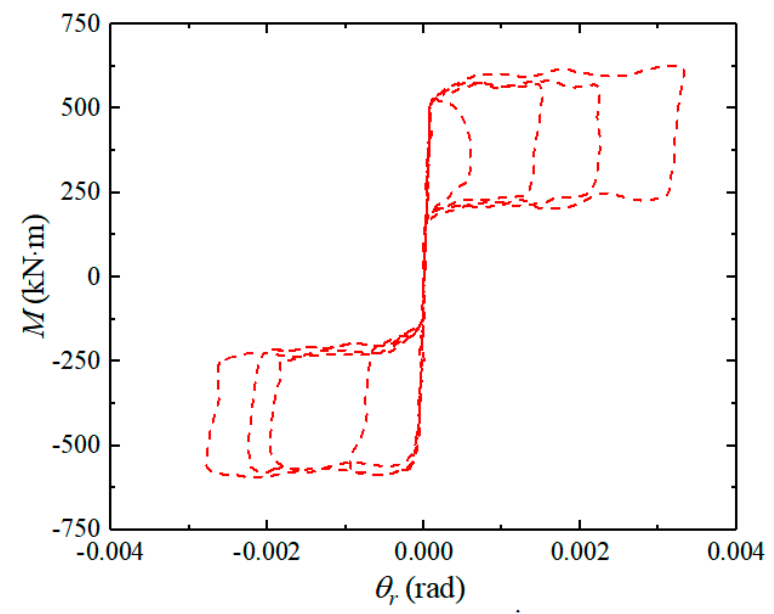

Figure 18. $M-\theta_{r}$ hysteretic relationships of the beam end joint for the new frame.

\subsection{Incremental Dynamic Analysis (IDA)}

Incremental dynamic analysis (IDA) is one of potential parameter analysis methods used in performance-based seismic engineering to assess the seismic behavior of the structure with the increase of the ground motion intensity. The technique includes a series of nonlinear dynamic analysis using one or more seismic ground motions multiplied by a series of proportional coefficients, to cover a whole dynamic performance of the structures with multiple intensities from elastic state to collapse state. To plot the IDA curves, the intensity measure (IM) of earthquake waves and the engineering demand parameters (EDP) are required. In this paper, 21 near-fault ground motions recommended by PEER record database are selected to conduct the IDA and assess the seismic behavior of novel SCPC structure. Select the proportional strength measurement index such as the acceleration response spectrum value corresponding to the first model period $S_{a}\left(T_{1}\right)$ as the intensity measure (IM), compared with other intensity measures such as the PGA and PGV. The EDP select the maximum inter-story drift ratio $\theta_{\text {max }}$ and the maximum residual inter-story drift ratio $\theta_{r, \max }$ to reflect seismic response at the near-fault earthquake waves. The acceleration response spectrum value corresponding to the first model period $S_{a}\left(T_{1}\right)$ change from $0.05 \mathrm{~g}$ to $0.6 \mathrm{~g}$, at an interval $0.05 \mathrm{~g}$. When applying the nonlinear dynamic history analysis on the novel SCPC frame, we can obtain the EDP index $\theta_{\max }$ and $\theta_{r, \max }$ for each near-fault earthquake wave. The relationship between the EDP $\theta_{\max }$ and $\theta_{r, \max }$ and the acceleration response spectrum value $S_{a}\left(\mathrm{~T}_{1}\right)$ are displayed in Figure 18. The figures illustrate the peak inter-story drift ratio 
and the peak residual inter-story drift ratio for each earthquake wave has a certain degree of dispersion and the dispersion increases with the increase of the seismic intensity.

For the probabilistic estimation of demand, the relationship between engineering demand parameters (EDP) and intensity measure $S_{a}\left(\mathrm{~T}_{1}\right)$ shows as follows:

$$
D=a(S I)^{b} \varepsilon
$$

where $a$ and $b$ denote the regression coefficient of linear regression analysis, SI refers to acceleration response spectrum value corresponding to the first model period $S_{a}\left(T_{1}\right), \varepsilon$ is lognormal distribution random variable with a median of 1.0 and logarithmic standard deviation of $\beta_{\mathrm{d}}$.

According to the Formula (4), regression analysis is conducted for the structural demands $\left(\theta_{\max }\right.$ and $\left.\theta_{r, \max }\right)$ and the regression curves can be obtained shown as in Figure 19. The figures also reflect the linear regression results together with 16 th percentile and 84 th percentile lines. It can be observed from the regression curves that both EDP index $\theta_{\max }$ and $\theta_{r, \max }$ of the novel SCPC structure nonlinear increased approximately with the seismic intensity of near-fault earthquake waves. However, the dispersion of the peak residual inter-story drift ratio is significantly larger than the peak inter-story drift ratio. The logarithmic standard deviation of the maximum inter-story drift ratio and the maximum residual inter-story drift ratio are 0.3767 and 0.9172 . It also presents the mean values of the peak story drift ratio of the novel SCPC frame are $0.34 \%$ and $0.83 \%$ at the two levels and the mean values of peak residual story drift ratios of the novel SCPC frame are $0.027 \%$ and $0.012 \%$ at the two seismic levels.

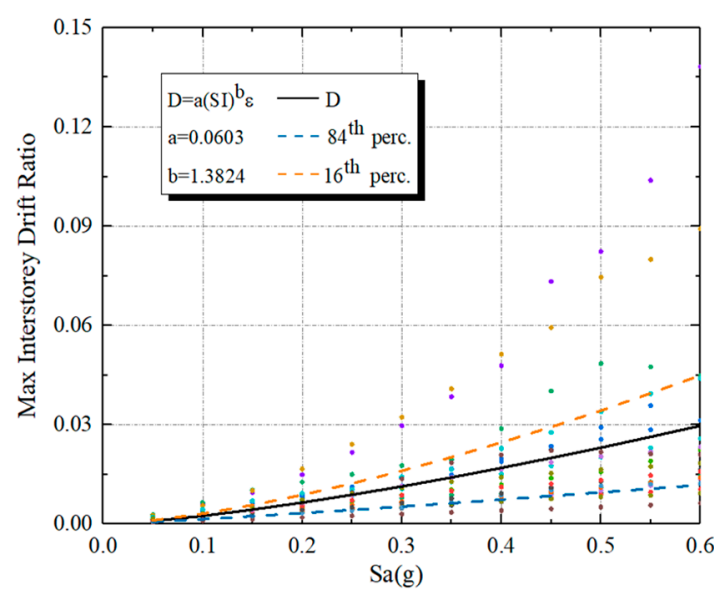

(a) Max inter-story drift ratio

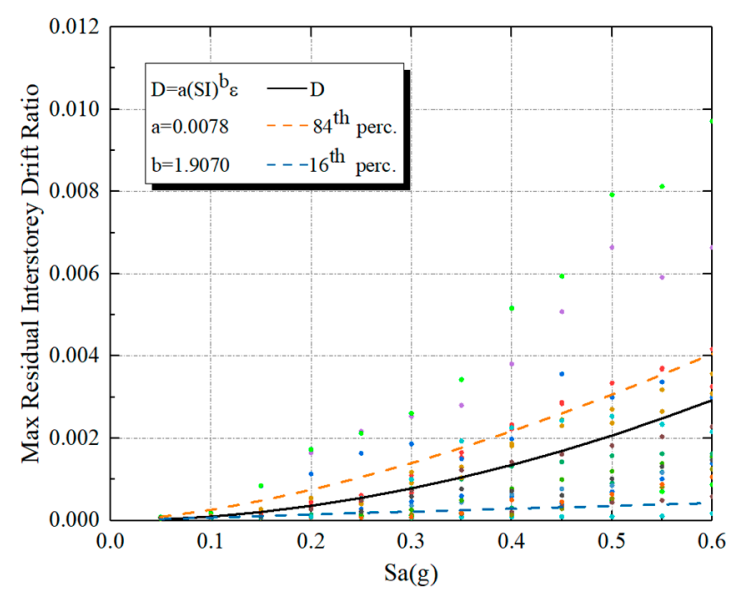

(b) Max residual inter-story drift ratio

Figure 19. The IDA curves of novel SCPC frame.

The seismic vulnerability of structures is a characteristic of the structure, which means the possibility of the structure reaching a certain limit state or performance level with the increasing of seismic intensities. The vulnerability analysis usually uses fragility curves to evaluate the seismic performance. The vulnerability function are defined as follows:

$$
F(x)=\sum_{x} P[L S \mid S I=x] .
$$

$F(x)$ refers to the seismic vulnerability of the structure, value $x$ refers to the value of certain seismic intensity corresponding to the SI. The structural fragility function can be described by a lognormal model corresponding the limit state shown as follows [46]:

$$
F(x)=\Phi\left[\frac{\ln x-\ln m_{R}}{\sqrt{\beta_{d}^{2}+\beta_{c}^{2}}}\right],
$$


where $\Phi$ is a standard normal distribution function, $m_{R}$ is median value of the fragility function, $\beta_{d}$, $\beta_{c}$ are assigned to logarithmic standard deviation of the structural demand, capacity respectively. $\beta_{d}$ can carried out by linear regression of the structural response under different intensities. $\beta_{c}$ means 0.3 to construct the fragility curves in this paper [47]. The seismic hazard probability model $H(\mathrm{x})$ represents the annual exceeding probability of the certain seismic intensity $S I$ at the certain site, which is related to the magnitude, epicenter distance and the attenuation regulation of ground motion [48]. If the seismic hazard probability is small, the simplified seismic hazard model can be used, the model is expressed as:

$$
H(x)=P[S I>x]=k_{0} x^{-k},
$$

where $k$ and $k_{0}$ are shape coefficient of seismic hazard curves, the values of $k$ and $k_{0}$ are subjected to four parameters-(1) annual exceeding probability with $10 \%$ exceeding probability in 50 years; (2) annual exceeding probability with $2 \%$ exceeding probability in 50 years; (3) $S_{a}\left(T_{1}\right)$ with $10 \%$ exceeding probability in 50 years; (4) $S_{a}\left(T_{1}\right)$ with $2 \%$ exceeding probability in 50 years.

Compared with the seismic hazard probability model, the seismic hazard curves of the novel SCPC frame under near-fault ground motions is shown in Figure 20. From seismic hazard curves and Chinese Standard Code [29], $S_{a}\left(T_{1}\right)$ and annual exceeding probability corresponding to the DBE level are 0.1176 and $1 / 475$, respectively, $S_{a}\left(T_{1}\right)$ and annual exceeding probability corresponding to the MCE level are 0.235 and $1 / 2475$, respectively.

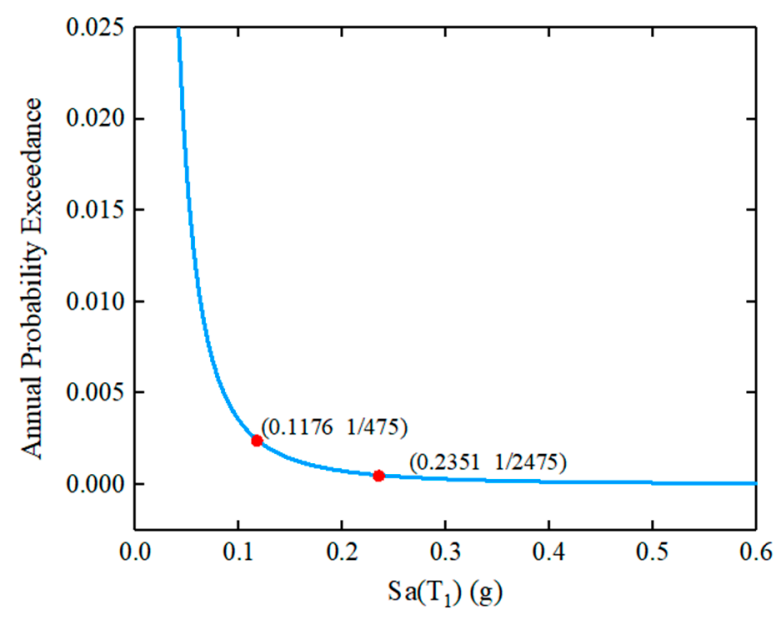

Figure 20. Seismic hazard curves of the novel SCPC frame.

Based on the fragility curves and the seismic hazard curves, the seismic risk assessment of a structure can be expressed by annual and 50-year exceeding probability of a certain limit state. The annual probability of exceeding a certain limit state can be calculated by the formula:

$$
P_{L S}=\int F(x) d H(x),
$$

combined with Formulas (6) and (7), the annual probability can be rewritten as follows:

$$
P_{L S}=\left(k_{0} m_{R}^{-k}\right) \exp \left[\frac{\left(k \beta_{R}\right)^{2}}{2}\right]
$$

the 50-year exceeding probability corresponding to a certain limit state can be written as follows:

$$
P_{L S / 50}=1-\left(1-P_{L S}\right)^{50} \text {. }
$$


Based on the theory of fragility analysis and the results of IDA analysis under near-fault earthquake wave, the fragility curves of the novel SCPC structure are plotted in Figure 21. The black and red curves represent the limit state of IO and RE for the engineering demand parameters including $\theta_{\max }$ and $\theta_{r, \max }$, respectively. From the fragility curves, the vertical lines represent the corresponding spectral acceleration $S_{a}\left(T_{1}\right)$ under the DBE and MCE levels, which are $0.117 \mathrm{~g}$ and $0.234 \mathrm{~g}$ calculated with $3 \%$ damping ratio of the novel SCPC frame. The vulnerability curves for the seismic limit state from IO to RE become smooth and move significantly toward the right, which means under the same $S_{a}$ $\left(T_{1}\right)$, the exceeding probabilities of the corresponding $\theta_{\max }$ and $\theta_{r, \max }$ drop obviously. The exceeding probabilities of each performance limit state for the novel frame are also shown in Table 3. At the DBE level, the exceeding probability is $5.5 \%$ for IO limit state and $0.58 \%$ for RE limit state with $\theta_{\max }$ as evaluating indicator and the exceeding probability is $1.90 \%$ for IO performance limit state and $0.19 \%$ for RE limit state with $\theta_{r, \max }$ as evaluating indicator. At the MCE level, the exceeding probability is $36.7 \%$ for IO limit state and $2.5 \%$ for RE limit state with $\theta_{\max }$ as evaluating indicator and the exceeding probability is $6.65 \%$ for IO performance limit state and $0.45 \%$ for RE limit state with $\theta_{r, \max }$ as evaluating indicator. Hence, the novel frame system has good seismic performance and less damage possibility under the IO and RE limit states.

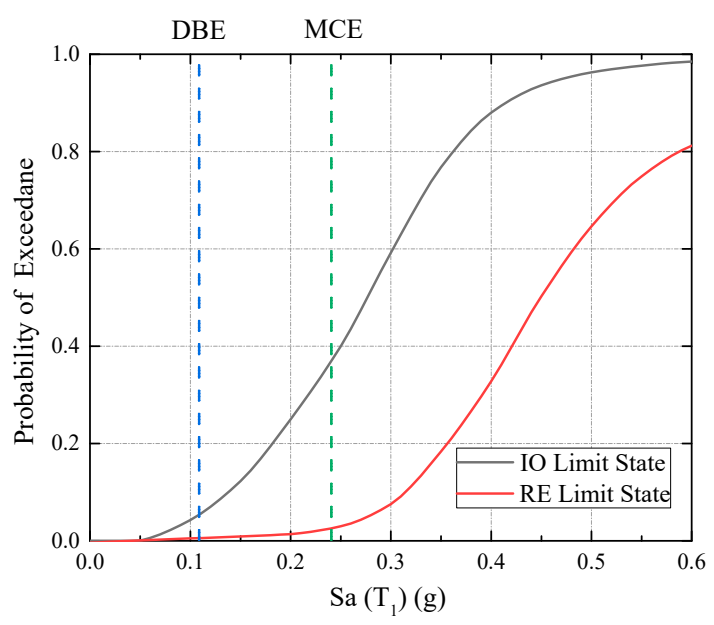

(a) Maximum inter-story drift ratio

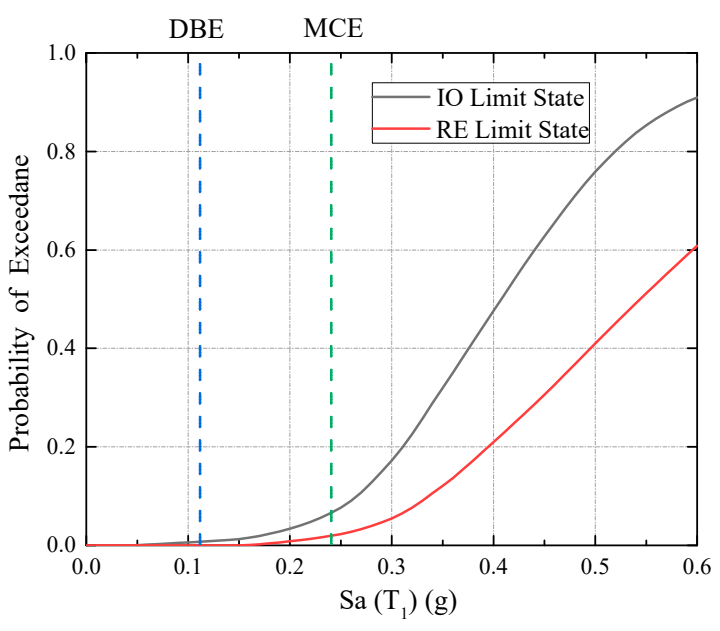

(b) Max residual inter-story drift ratio

Figure 21. Fragility curves of novel SCPC frames (engineering demand parameters (EDP) of $\theta_{\max }$ and $\theta_{r, \max }$ ).

Table 3. Exceeding probabilities of the two performance limit states.

\begin{tabular}{ccccc}
\hline \multirow{2}{*}{ Earthquake Level } & \multicolumn{2}{c}{ Exceeding Probability $\left(\%, \boldsymbol{\theta}_{\max }\right)$} & \multicolumn{2}{c}{ Exceeding Probability $\left(\%, \boldsymbol{\theta}_{\boldsymbol{r}, \max }\right)$} \\
\cline { 2 - 5 } & IO & RE & IO & RE \\
\hline DBE level & 5.50 & 0.58 & 1.90 & 0.19 \\
MCE level & 36.70 & 2.50 & 6.65 & 0.45 \\
\hline
\end{tabular}

Based on the Chinese Standard Code [29], the DBE and MCE levels have 10\% and 2\% 50-year exceeding probabilities, respectively. The design objective of the novel SCPC frame can be also summarized as-the 50-year exceeding probability of IO performance limit state is less than $10 \%$ and the 50-year exceeding probability of RE performance limit state is less than $2 \%$. Based on the structural fragility analysis and seismic hazard analysis theory, the annual and 50-year exceeding probabilities of different limit states are shown in Figure 22. When the EDP $\theta_{\max }$ is taken as the evaluating indicator, the annual exceeding probabilities of the novel frame are $0.0628 \%$ and $0.0159 \%$ for the IO and RE limit state and the 50-year exceeding probabilities of the novel frame are $3.09 \%$ and $0.79 \%$ for the IO and RE limit state, respectively. When the EDP $\theta_{r, \max }$ is taken as the evaluating indicator, the annual exceeding probabilities of the novel frame are $0.0263 \%$ and $0.0045 \%$ for the IO and RE limit state, the 50 -year exceeding probabilities are $1.31 \%$ and $0.23 \%$ for the IO and RE limit state, respectively. Therefore, 
according to the seismic risk assessment of different performance limit states based on structural fragility and seismic hazard analysis theory, the novel SCPC frame can satisfy the seismic limit state and has great structural reliability under the near-fault ground motions.

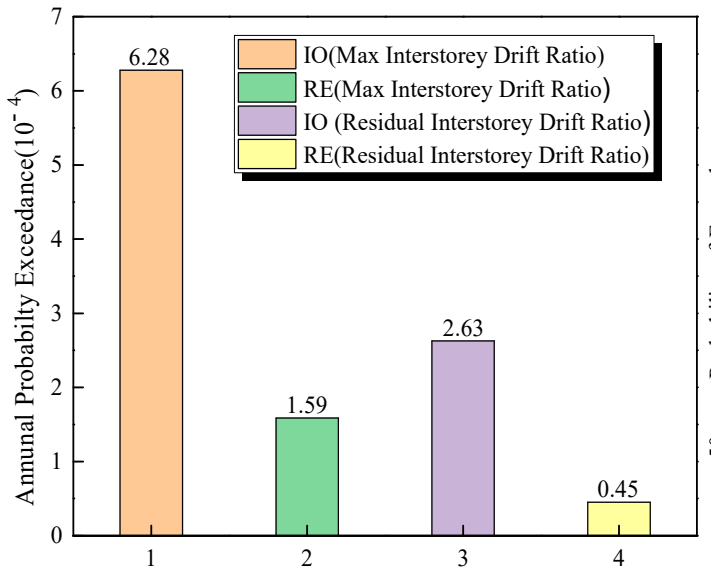

(a) Annual and 50-year exceeding probabilities

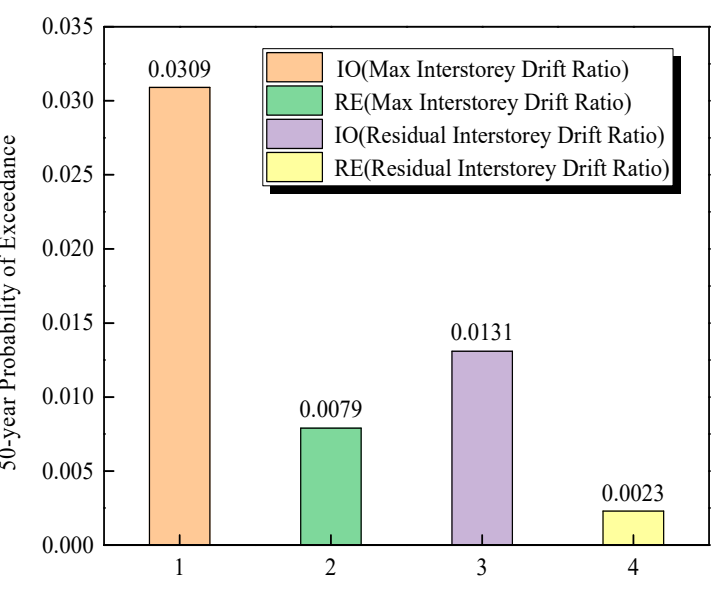

(b) 50-year exceeding probabilities

Figure 22. Annual and 50-year exceeding probabilities of novel SCPC frame under near-fault earthquake waves.

\section{Further Discussion}

To verify the great seismic behavior of the novel SCPC frame under near-fault earthquake waves and the accuracy of seismic risk assessment of numerical model, a five-story four-span cast-in-place RC frame (a reinforced concrete frame) and the traditional SCPC frame (a traditional self-centering precast concrete frame without hysteretic dampers) have been modelled by OpenSees. The section sizes and reinforcements arrangement of the two frames are consistent with the prototype structures.

Figure 23a displays the analytical connection model of the RC frame; all the structure members are simulated by the Nonlinear Beam Column element. The Joint2D element is adopted in the modelling of the connection core area and is idealized as a parallelogram shaped shear panel with adjacent elements connected to its mid-points. The Joint2D element includes a spring element inside the joint to represent the shear behavior of the core area and four spring elements located at the beam column interface to simulate the sliding the pulling out of reinforcements. The hysteretic curves of force and deformation of each spring can be simulated by the Pinching 4 material model [49]. The Pinching 4 material model also reflects the pinching effect, degradation effect of stiffness and strength under cyclic loading. The analytical model of the traditional SCPC frame (shown in Figure 23b) and the modelling method of the novel joint are close to the aforementioned novel SCPC beam-column connection. The concrete is also assigned to the Concrete 01 material model and the enhancement factor of the stirrup restraint effect is 0.2 . The steel bars and PT tendons are also assigned to the Steel 02 material model, which are also based on the Giuffre-Menegotto-Pinto model. Because there are no hysteretic dampers to dissipate energy, the two pairs of zeroLength spring elements simulate the gap of connection opening and closing at the end of the beam under earthquake actions. The shear slip at the beam-column interface is avoided when gap has opened. The rigidlink elements are selected to reflect the coupling characteristics between the node of gaps and the relevant nodes of structural components. The Truss element is also used to simulate the unbonded PT tendons between node 7 and node 12 for connection of the traditional SCPC frame. 


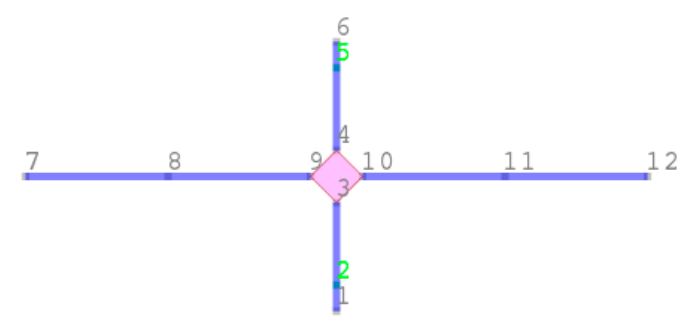

(a) Analytical connection model of RC frame

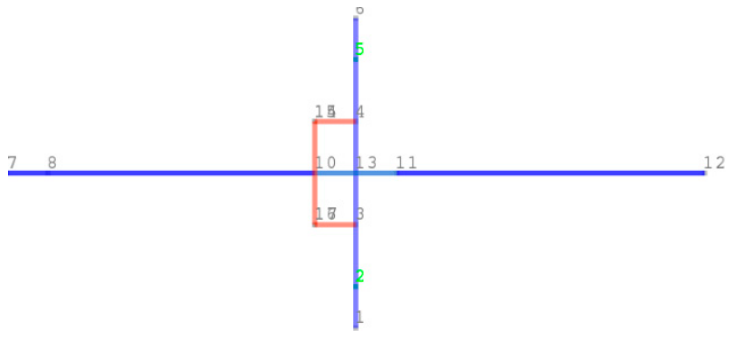

(b) Analytical connection model of traditional SCPC frame

Figure 23. Analytical connection model of RC frame and traditional SCPC frame.

The site class and seismic intensity are similar to the prototype structures, 21 near-fault earthquake waves from PEER record database are also chosen for the elastoplastic dynamic analysis for the RC frame and the traditional SCPC frame. The peak ground acceleration of selected ground motions are all satisfy the DBE and MCE levels through linearly scaled. The damping ratio of the Rayleigh damper is $5 \%$ for the RC structure and 3\% for the traditional SCPC structure, respectively. Tenety second last-time free vibration analysis of the frames are also continued after the applying each near-fault ground motion to calculate the residual deformation.

The peak inter-story drift ratios $\theta_{\max }$ of the three frames for each near-fault ground motion and for each story at the DBE and MCE levels are displayed in Figure 24a,b. Figure 24a indicates that the peak inter-story drift ratios of the traditional SCPC frame are the largest and the novel SCPC frame are the smallest subjected to each earthquake wave at the DBE and MCE levels. The maximum difference between the maximum response of the RC frame and the novel SCPC frame subjected to all the earthquake waves are $11.3 \%$ and $12.6 \%$ at the DBE and MCE level. The maximum difference between the maximum response of the traditional SCPC frame and the novel SCPC frame subjected to all the earthquake waves is $26.4 \%$ and $13.8 \%$ at the DBE and MCE levels, respectively. The mean value of the peak story drift ratios of the RC structure subjected to all the earthquake waves are $0.36 \%$ and $0.88 \%$ subjected to the two levels. And the mean value of peak story drift ratios of the traditional SCPC structure corresponding to all the earthquake waves are $0.40 \%$ and $0.91 \%$ subjected to the two levels.

Figure $24 \mathrm{~b}$ shows that the peak inter-story drift ratios of the traditional SCPC structure are the largest and the novel SCPC frame are the smallest for each story under the two levels. The maximum responses of all the stories all happen on the second story for the three structures. The peak responses for the RC frame are equal to $0.72 \%, 0.54 \%, 0.31 \%$ from the third to top story at the MCE level and the maximum responses for the traditional SCPC frame are $0.76 \%, 0.58 \%, 0.33 \%$ from the third to fifth story at the MCE level. From the results of the three frames, the extent of gap opening of the novel SCPC frame is small at the DBE level, in addition to the initial stiffness provided by the hysteretic dampers, the peak inter-story drift ratios of the novel frame are relatively small. When the gap opening becomes larger and the bending stiffness significantly decreases under the MCE level, the frame has been in a plastic state. The hysteretic dampers dissipate seismic energy after yielding; the peak responses of the novel frame are still the smallest of the three frames. It contributes the high initial stiffness and better dissipates seismic energy capacity after the yielding provided by the hysteretic dampers.

Figure 25 displays the peak residual inter-story drift ratios $\theta_{r, \max }$ of the three frames for each story at the DBE and MCE levels subjected to the near-fault earthquake waves. The peak residual inter-story drift ratios of the three frames for each story are far below the limiting value of $0.2 \%$ and $0.5 \%$ at the DBE and MCE levels. The maximum residual responses of the RC frame for each story are significantly larger than the novel SCPC frame and the traditional SCPC frame. The peak residual story drift ratios of the RC frame for all the stories are $1.28 \times 10^{-4} \mathrm{rad}$ and $6.54 \times 10^{-4} \mathrm{rad}$ at the DBE and MCE levels and happen on the first floor. The peak residual story drift ratios of the novel SCPC frame and traditional SCPC frame are similar and close to zero, which attributes the good self-centering capability of the two self-centering precast concrete frames. 

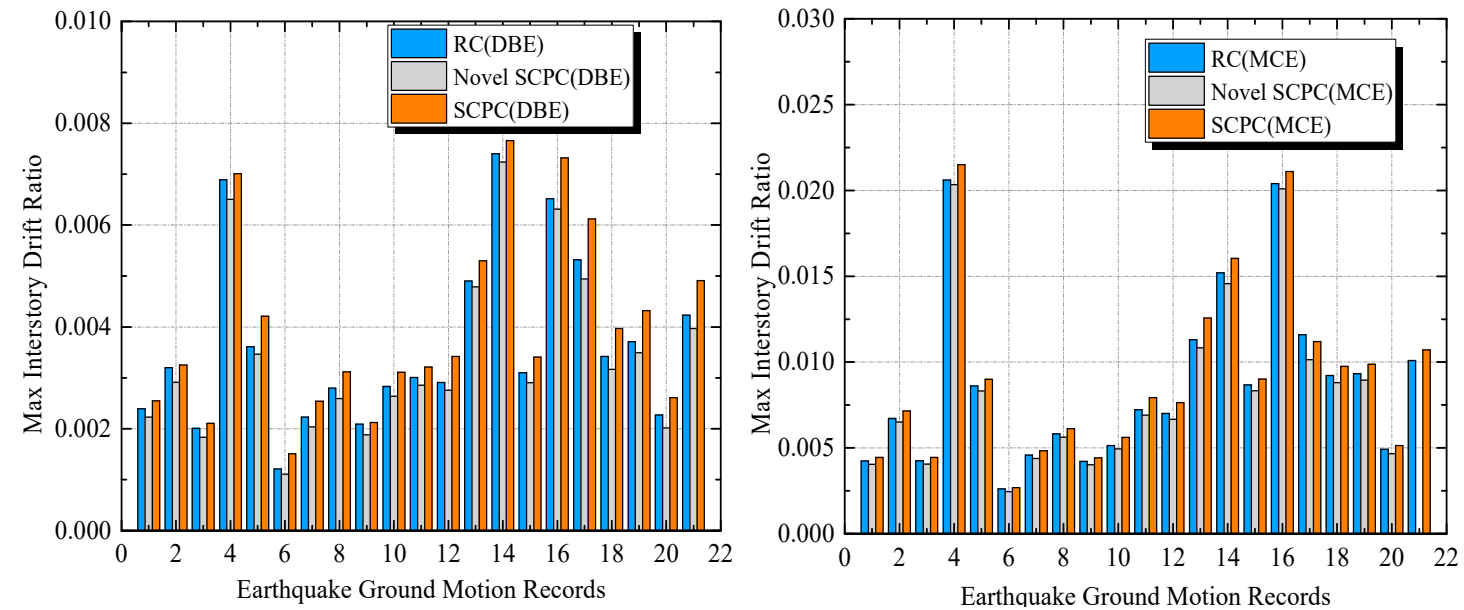

(a) Maximum inter-story drift ratios $\theta_{\max }$ of the three frames for each near-fault ground motion.
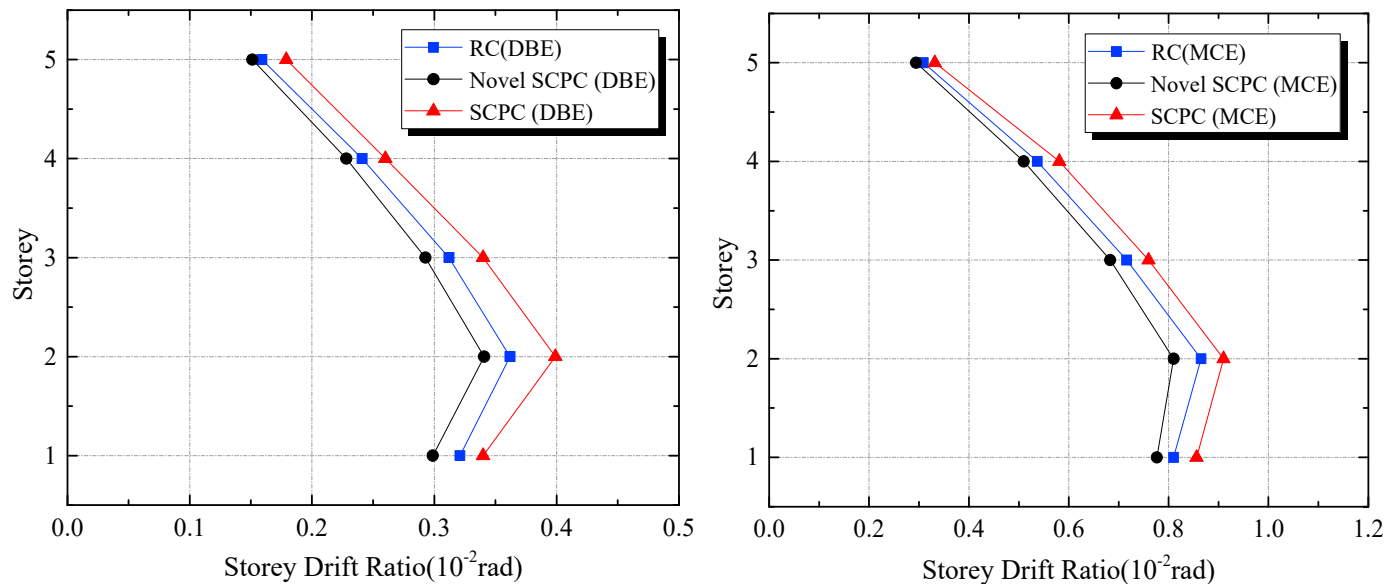

(b) Maximum inter-story drift ratios $\theta_{\max }$ of the three frames for each story.

Figure 24. Maximum inter-story drift ratios of three frames at DBE and MCE level.

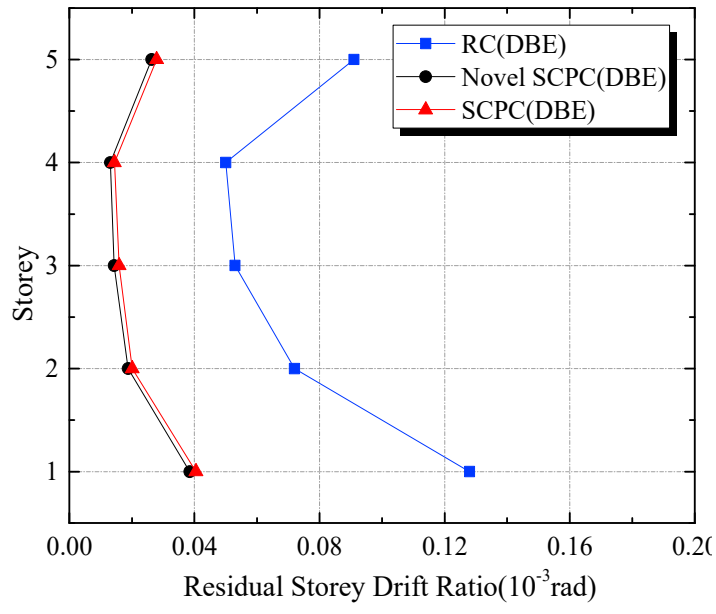

(a) DBE level

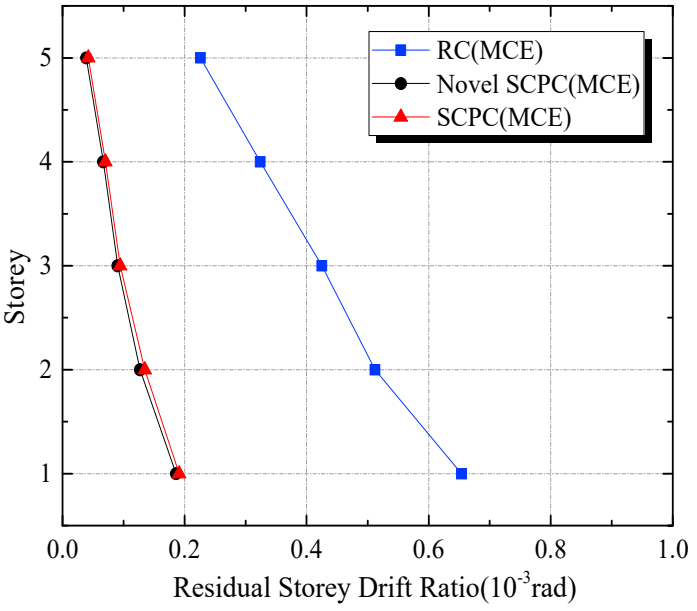

(b) MCE level

Figure 25. Maximum residual inter-story drift ratios of three frames at DBE and MCE level. 
The maximum inter-story shear forces of the three frames for each earthquake wave and for each story at the DBE and MCE level are displayed in Figures 26a and 26b, respectively. It shows that the maximum inter-story shear force of the RC structure is the largest of the three frames. The peak inter-story shear force of the RC frame and the traditional SCPC frame are $1034 \mathrm{kN}$ and $1001 \mathrm{kN}$, corresponding to 21 earthquake waves at the MCE level, respectively. The peak responses of the RC structure and the traditional SCPC structure for all the stories are $710 \mathrm{kN}$ and $687 \mathrm{kN}$ under the MCE level and both happen on the first floor. Due to the different construction mechanisms of the beam-column connections of different concrete frames, horizontal earthquake action will weaken with the increase of natural periods of the novel SCPC frame and the traditional SCPC frame, in addition to the better energy dissipation provided by the hysteretic dampers. Therefore, the inter-story shear force of the novel SCPC frame is the smallest at the MCE level.
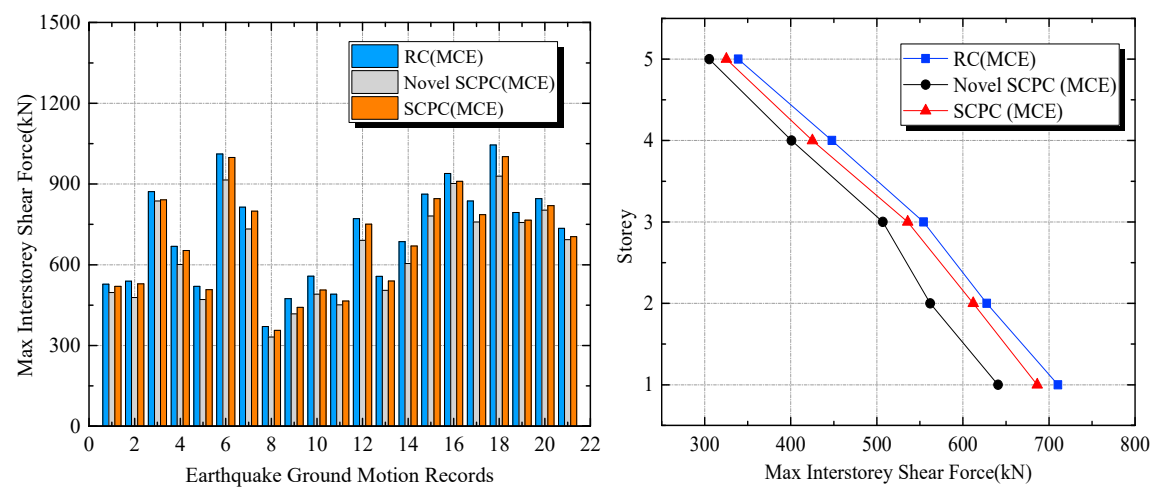

(a) Max inter-story shear force for each ground motion (b) Max inter-story shear force for each story.

Figure 26. Maximum inter-story shear force of three frames at MCE level.

The maximum connection rotations and PT tendons forces of the traditional SCPC structure and novel SCPC structure at the MCE level are also drawn in Figure 27. It illustrates-(1) the peak connection rotation of the traditional SCPC frame for each story is obviously larger than that of the novel SCPC frame. The maximum connection rotation of the traditional SCPC frame for all the stories is $3.38 \times 10^{-3} \mathrm{rad}$ and happens on the first story, then decreases gradually. The maximum difference between the maximum rotations of the two SCPC frames for all the stories are $26.7 \%$ under the MCE level; (2) The PT tendons forces of the traditional SCPC frame are also significantly larger than the novel frame at the MCE level and the change regulation of PT force in each story of the two frames are relatively homogeneous. The maximum tendon force of the traditional SCPC frame happens on the second floor, which is 0.67 times the yielding tendon force at the MCE level. It reflects that the PT forces of the two SCPC frames are still in the elastic stage and the good energy consumption characteristic of the novel SCPC frame at the MCE level.

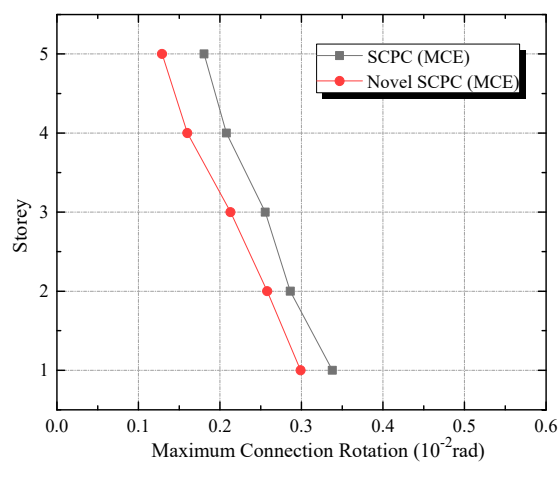

(a) The traditional SCPC frame

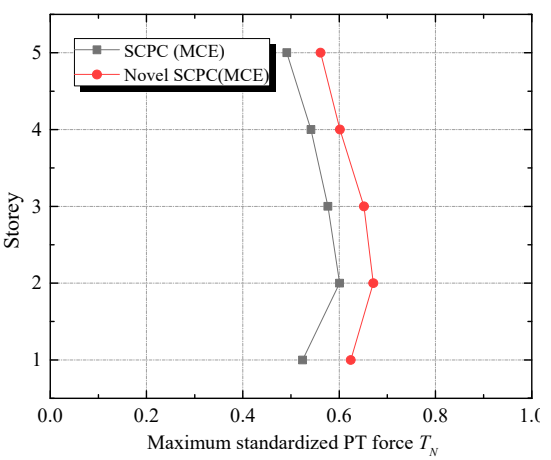

(b) The novel SCPC structure

Figure 27. Maximum connection rotation and standardized PT force of two SCPC frames. 


\section{Conclusions}

This study develops a new self-centering precast concrete (SCPC) frame with hysteretic dampers. The configuration and working principles of beam-column connections are illustrated. A prototype structure is modelled and the elastoplastic dynamic responses at the DBE and MCE levels are studied. IDA and seismic fragility analysis are also carried out. In addition, the elastoplastic dynamic responses of the RC structure and the traditional SCPC structure are also studied. From the aforementioned research, the main conclusions are summarized:

1. The novel SCPC frame can satisfy the seismic target under near-fault earthquake waves. The peak and residual inter-story drift ratios all achieve the desirable demands at the DBE and MCE levels. The maximum inter-story shear forces indicate the novel frame can undertake more load due to the large stiffness. The maximum connection relative rotations are minimal and PT forces are all below the yielding tendon force at the MCE level to maintain the self-recovering characteristic. Besides, the beam end $M-\theta_{r}$ relation curves of the novel joint are stable and display a typical double-flag shape.

2. The results of IDA indicate the peak and residual inter-story drift ratios both nonlinearly increase approximately with the increasing intensity under near-fault earthquake waves. The dispersion degree of the peak residual inter-story drift ratios is significantly higher than that of the peak inter-story ratios and the dispersion increases with increasing intensity levels.

3. The fragility curves for the seismic limit state from IO to RE become smooth and move significantly toward the right, which means under the same $S_{a}\left(\mathrm{~T}_{1}\right)$ the exceeding probabilities of the corresponding $\theta_{\max }$ and $\theta_{r, \max }$ drop obviously. Based on the fragility analysis and seismic hazard analysis, the 50-year exceeding probabilities can be obtained and satisfy the seismic design objective.

4. The peak inter-story drift ratios of the traditional SCPC frame are the largest of the three frames under near-fault earthquake waves loading. The peak residual inter-story drift ratios and the peak inter-story shear forces of the RC frame are the largest; the peak residual inter-story drift ratios of two SCPC frames are minimal. The maximum connection rotations and PT tendons forces of the traditional SCPC frame are significantly larger than those of the novel SCPC frame. The results show that the SCPC frame with hysteretic dampers has great seismic behavior, energy consumption and self-recovering capacities under near-fault earthquake waves loading.

Author Contributions: Original ideas F.G. and Y.D.; data curation, F.G., H.W. and K.Y; funding acquisition, Y.D.; methodology, F.G. and H.W.; writing_original draft preparation F.G.; writing-review and editing, F.G. and K.Y. All authors have read and agreed to the published version of the manuscript.

Funding: The authors gratefully appreciate the support of Program of National Natural Science Foundation (Nos.51608258, 51978154), the Distinguished Young Scientists of Jiangsu Province (No. BK20190013), the Jiangsu Government Scholarship for Overseas Studies (grant number: JS-2018-074), the Program of China Postdoctoral Foundation (No. 2019M651595), Six Peak High Talent Projects of Jiangsu Province (No. JZ-032), the Fundamental Research Fund for Tongji Architectural Design (Group) (No. 2017KY13).

Conflicts of Interest: The authors declare no conflict of interest.

\section{References}

1. Mavroeidis, G.P.; Papageorgiou, A.S. A mathematical representation of near-fault ground motions. Bull. Seismol. Soc. Am. 2003, 93, 1099-1131. [CrossRef]

2. Adanur, S.; Altunişik, A.C.; Bayraktar, A.; Akköse, M. Comparison of near-fault and far-fault ground motion effects on geometrically nonlinear earthquake behavior of suspension bridges. Nat. Hazards 2012, 64, 593-614. [CrossRef]

3. Somerville, P.G. Magnitude scaling of the near fault rupture directivity pulse. Phys. Earth Planet. Inter. 2003, 137, 201-212. [CrossRef] 
4. Alavi, B.; Krawinkler, H. Strengthening of moment-resisting frame structures against near-fault ground motion effects. Earthq. Eng. Struct. Dyn. 2004, 33, 707-722. [CrossRef]

5. Yadav, K.K.; Gupta, V.K. Near-fault fling-step ground motions: Characteristics and simulation. Soil Dyn. Earthq. Eng. 2017, 101, 90-104. [CrossRef]

6. Phan, V.; Saiidi, M.S.; Anderson, J.; Ghasemi, H. Near-fault ground motion effects on reinforced concrete bridge columns. J. Struct. Eng. 2007, 133, 982-989. [CrossRef]

7. Takewaki, I.; Tsujimoto, H. Scaling of design earthquake ground motions for tall buildings based on drift and input energy demands. Earthq. Struct. 2011, 2, 171-187. [CrossRef]

8. Chioccarelli, E.; Iervolino, I. Near-source seismic hazard and design scenarios. Earthq. Eng. Struct. Dyn. 2013, 42, 603-622. [CrossRef]

9. Tothong, P.; Cornell, C.A. Structural performance assessment under near-source pulse-like ground motions using advanced ground motion intensity measures. Earthq. Eng. Struct. Dyn. 2008, 37, 1013-1037. [CrossRef]

10. Champion, C.; Liel, A. The effect of near-fault directivity on building seismic collapse risk. Earthq. Eng. Struct. Dyn. 2012, 41, 1391-1409. [CrossRef]

11. Mazza, F.; Vulcano, A. Effects of near-fault ground motions on the nonlinear dynamic response of base-isolated rc framed buildings. Earthq. Eng. Struct. Dyn. 2012, 41, 211-232. [CrossRef]

12. Mortezaei, A.; Ronagh, H.R.; Kheyroddin, A. Seismic evaluation of FRP strengthened RC buildings subjected to near-fault ground motions having fling step. Compos. Struct. 2010, 92, 1200-1211. [CrossRef]

13. Alavi, B.; Krawinkler, H. Behavior of moment-resisting frame structures subjected to near-fault ground motions. Earthq. Eng. Struct. Dyn. 2004, 33, 687-706. [CrossRef]

14. Loh, C.H.; Wan, S.; Liao, W.I. Effects of hysteretic model on seismic demands: Consideration of near-fault ground motions. Struct. Des. Tall Build. 2002, 11, 155-169. [CrossRef]

15. Sehhati, R.; Rodriguez-Marek, A.; ElGawady, M.; Cofer, W.F. Effects of near-fault ground motions and equivalent pulses on multi-story structures. Eng. Struct. 2011, 33, 767-779. [CrossRef]

16. Soleimani Amiri, F.; Ghodrati Amiri, G.; Razeghi, H. Estimation of seismic demands of steel frames subjected to near-fault earthquakes having forward directivity and comparing with pushover analysis results. Struct. Des. Tall Spec. Build. 2013, 22, 975-988. [CrossRef]

17. Ricles, J.M.; Sause, R.; Garlock, M.M.; Zhao, C. Posttensioned seismic-resistant connections for steel frames. J. Struct. Eng. 2001, 127, 113-121. [CrossRef]

18. Rojas, P.; Ricles, J.M.; Sause, R. Seismic performance of post-tensioned steel moment resisting frames with friction devices. J. Struct. Eng. 2005, 131, 529-540. [CrossRef]

19. Lin, Y.C.; Sause, R.; Ricles, J. Seismic performance of a large-scale steel self-centering moment-resisting frame: MCE hybrid simulations and quasi-static pushover tests. J. Struct. Eng. 2013, 139, 1227-1236. [CrossRef]

20. Priestley, M.N.; Tao, J.R. Seismic response of precast prestressed concrete frames with partially debonded tendons. PCI J. 1993, 38, 58-69. [CrossRef]

21. El-Sheikh, M.; Pessiki, S.; Sause, R.; Lu, L.W. Moment rotation behavior of unbonded post-tensioned precast concrete beam-column connections. Struct. J. 2000, 97, 122-131.

22. Cheok, G.S.; Stone, W.C.; Kunnath, S.K. Seismic response of precast concrete frames with hybrid connections. Struct. J. 1998, 95, 527-539.

23. Morgen, B.G.; Kurama, Y.C. Seismic design of friction-damped precast concrete frame structures. J. Struct. Eng. 2007, 133, 1501-1511. [CrossRef]

24. Rodgers, G.W.; Mander, J.B.; Geoffrey Chase, J. Modeling cyclic loading behavior of jointed precast concrete connections including effects of friction, tendon yielding and dampers. Earthq. Eng. Struct. Dyn. 2012, 41, 2215-2233. [CrossRef]

25. Rodgers, G.W.; Solberg, K.M.; Mander, J.B.; Chase, J.G.; Bradley, B.A.; Dhakal, R.P. High-force-to-volume seismic dissipators embedded in a jointed precast concrete frame. J. Struct. Eng. 2012, 138, 375-386. [CrossRef]

26. Lu, X.; Cui, Y.; Liu, J.; Gao, W. Shaking table test and numerical simulation of a 1/2-scale self-centering reinforced concrete frame. Earthq. Eng. Struct. Dyn. 2015, 44, 1899-1917. [CrossRef]

27. Seo, C.Y.; Sause, R. Ductility demands on self-centering systems under earthquake loading. Aci Struct. J. 2005, 102, 275.

28. MOHURD. Code for Design of Concrete Structures; MOHURD: Beijing, China, 2010; GB50010-2010.

29. MOHURD. Code for Seismic Design of Buildings; MOHURD: Beijing, China, 2010; GB50011-2010.

30. MOHURD. Load Code for the Design of Building Structures; MOHURD: Beijing, China, 2012; GB50009-2012. 
31. FEMA (Federal Emergency Management Agency). Commentary for the Seismic Rehabilitation of Buildings (FEMA-356); FEMA: Washington, DC, USA, 2000.

32. Wang, G.Q.; Zhou, X.Y.; Zhang, P.Z.; Igel, H. Characteristics of amplitude and duration for near fault strong ground motion from the 1999 Chi-Chi, Taiwan earthquake. Soil Dyn. Earthq. Eng. 2002, 22, 73-96. [CrossRef]

33. Burks, L.S.; Baker, J.W. A predictive model for fling-step in near-fault ground motions based on recordings and simulations. Soil Dyn. Earthq. Eng. 2016, 80, 119-126. [CrossRef]

34. MOHURD. Specification for Seismic Design of Prestressed Concrete Structures; JGJ 140-2004; MOHURD: Beijing, China, 2012.

35. Mazzoni, S.; Mckenna, F.; Scott, M.H.; Fenves, G.L. Opensees Command Lang. Munual; Pacific Earthquake Engineering Research (PEER) Center: Berkeley, CA, USA, 2007.

36. Kent, D.C.; Park, R. Flexural members with confined concrete. J. Struct. Div. 1971, 97, 1969-1990.

37. Lai, M.H.; Liang, Y.W.; Wang, Q.; Ren, F.M.; Chen, M.T.; Ho, J.C. A stress-path dependent stress-strain model for FRP-confined concrete. Eng. Struct. 2020, 203, 109824. [CrossRef]

38. Lai, M.H.; Chen, M.T.; Ren, F.M.; Ho, J.C. Uni-axial behaviour of externally confined UHSCFST columns. Thin Walled Struct. 2019, 142, 19-36. [CrossRef]

39. Lai, M.; Hanzic, L.; Ho, J.C. Fillers to improve passing ability of concrete. Struct. Concr. 2019, 20, 185-197. [CrossRef]

40. Lai, M.H.; Ho, J.C. Confinement effect of ring-confined concrete-filled-steel-tube columns under uni-axial load. Eng. Struct. 2014, 67, 123-141. [CrossRef]

41. Menegotto MPinto, P.E. Method of analysis for cyclically loaded reinforced concrete plane frames including changes in geometry and non-elastic behavior of elemets under combined normal force and bending. In Proceedings of the IABSE Symposium, Lisbon, Protugal, 27-29 March 1973; Volume 13, pp. 15-22.

42. Iyama, J.; Seo, C.; Ricles, J.M.; Sause, R. Self-centering moment resisting frames MRFs with bottom flange friction devices under earthquake loading. J. Constr. Steel Res. 2009, 65, 314-325. [CrossRef]

43. Pam, H.J.; Ho, J.C. Length of critical region for confinement steel in limited ductility high-strength reinforced concrete columns. Eng. Struct. 2009, 31, 2896-2908. [CrossRef]

44. Ho, J.C.; Pam, H.J. Inelastic design of low-axially loaded high-strength reinforced concrete columns. Eng. Struct. 2003, 25, 1083-1096. [CrossRef]

45. Feng, D.C.; Wu, G.; Lu, Y. Finite element modelling approach for precast reinforced concrete beam-to-column connections under cyclic loading. Eng. Struct. 2018, 174, 49-66. [CrossRef]

46. Ellingwood, B.R.; Kinali, K. Quantifying and communicating uncertainty in seismic risk assessment. Struct. Saf. 2009, 31, 179-187. [CrossRef]

47. Celik, O.C.; Ellingwood, B.R. Seismic fragilities for non-ductile reinforced concrete frames-Role of aleatoric and epistemic uncertainties. Struct. Saf. 2010, 32, 1-2. [CrossRef]

48. Cornell, C.A.; Jalayer, F.; Hamburger, R.O.; Foutch, D.A. Probabilistic basis for 2000 SAC federal emergency management agency steel moment frame guidelines. J. Struct. Eng. 2002, 128, 526-533. [CrossRef]

49. Celik, O.C.; Ellingwood, B.R. Modeling beam-column joints in fragility assessment of gravity load designed reinforced concrete frames. J. Earthq. Eng. 2008, 12, 357-381. [CrossRef]

(C) 2020 by the authors. Licensee MDPI, Basel, Switzerland. This article is an open access article distributed under the terms and conditions of the Creative Commons Attribution (CC BY) license (http://creativecommons.org/licenses/by/4.0/). 